\title{
From Handmaidens to POSH Humanitarians: The Case for Making Human Capabilities the Business of I-O Psychology
}

\author{
Alexander Gloss \\ North Carolina State University \\ Stuart C. Carr \\ Massey University \\ Walter Reichman \\ OrgVitality \\ Inusah Abdul-Nasiru \\ University of Ghana \\ W. Trevor Oestereich \\ North Carolina State University
}

\begin{abstract}
Industrial-organizational (I-O) psychology has begun to shed its reputation as a handmaiden to corporate and managerial interests, in part, through its engagement with humanitarian concerns. However, as highlighted by recent commentary, I-O psychology still has a decidedly POSH perspective on the world; that is, it has focused on Professionals who hold Official jobs in a formal economy and who enjoy relative Safety from discrimination while also living in High-income countries. This POSH perspective reflects an underlying bias away from people living in multidimensional poverty. We empirically illustrate some of the connections between a POSH perspective and poverty by reviewing 100 years of research in I-O psychology, and then we make a case for why a neglect of people living in poverty undermines the discipline's science, its practice, and its humanist charge. As moral justification for greater engagement with humanitarian concerns and as a guide to navigate the difficult ethical quandaries involved in doing so, we suggest that I-O psychologists should consider the capability approach. We discuss the concept of human capabilities,
\end{abstract}

Alexander Gloss, Department of Psychology, North Carolina State University; Stuart C. Carr, School of Psychology, Massey University; Walter Reichman, OrgVitality; Inusah AbdulNasiru, Department of Psychology, University of Ghana; W. Trevor Oestereich, North Carolina State University.

This research was supported in part by a grant from the United States National Science Foundation (DGE-0750733). We wish to acknowledge the unusually generous support and patience of all those who expertly reviewed previous versions of this manuscript.

Correspondence concerning this article should be addressed to Alexander Gloss, Department of Psychology, North Carolina State University, 640 Poe Hall, Campus Box 7650, Raleigh, NC 27695-7650. E-mail: alexandergloss@gmail.com 
relate it to I-O psychology, and demonstrate its utility in the form of three hypothetical scenarios. Perhaps our most controversial claim is that there is a moral imperative for I-O psychology to overrepresent people living in the deepest forms of poverty in both its science and practice.

Keywords: humanitarian, poverty, capability approach, humanist, justice

The purpose of this article is to make the case that (a) despite an increasing focus on humanistic and humanitarian issues, industrial-organizational (I-O) psychology ${ }^{1}$ has a fundamental and pervasive bias toward people who are relatively free from the worst ravages of poverty; (b) such a bias presents scientific, practice-related, and moral problems for I-O psychology; and (c) the capability approach championed by the Nobel Prize-winning political philosopher and economist Amartya Sen (1999) provides both moral justification to overrepresent people living in poverty and a useful conceptual guide for I-O psychology as it engages with humanitarian concerns.

We make the above case in four main sections. First, we discuss the nature of I-O psychology's transition away from predominately corporate and managerial interests toward an increasing adoption of the scientistpractitioner-humanist model (Lefkowitz, 1990) and the discipline's increasing engagement with humanitarian concerns. We view humanitarian concerns as a subset of humanist concerns, with "humanist" referring to the consideration of all aspects of human well-being, whereas "humanitarian" relates more specifically to basic or fundamental aspects of well-being (e.g., alleviating extreme poverty, assisting populations in war-torn areas, and responding to natural disasters). Second, we synthesize existing commentaries to argue that I-O psychology's perspective can be broadly described as POSH, ${ }^{2}$ that is, biased toward Professionals (Bergman \& Jean, 2016), Official work in the formal economy (Saxena et al., 2015), groups that are relatively Safe from discrimination (Ruggs et al., 2013), and citizens of High-income countries (Gelfand, Leslie, \& Fehr, 2008). Together these commentaries help to reflect a pervasive neglect of people living in poverty. We define poverty not just as a dearth of financial resources but as a multidimensional phenomenon characterized by a lack of personal freedoms to participate effectively in society (Sen, 1999). ${ }^{3}$ We also argue why a neglect of people

1 We use the term I-O psychology to conform with the title of this journal. However, we note that other names for the discipline (e.g., organizational psychology, work psychology, etc.) are often more prevalent outside of the United States.

2 The term "posh" according to the Oxford English Dictionary (www.oed.com) signifies, among other things, being typical of or belonging to the upper class.

3 With this definition, a person who willingly chooses to live an ascetic and financially destitute lifestyle might not be considered "poor." In contrast, someone who can provide financially for his or her own health and well-being might still be impoverished if there are physical, social, or political boundaries to their effective participation in society. 
living in poverty is a problem for I-O psychology's science and practice. Third, we introduce the concept of human capabilities and demonstrate its usefulness in helping to balance concerns for universal human justice and problems of cultural relativity, especially in humanitarian situations. We relate the concept of capabilities to concepts in I-O psychology and make a case for its utility to the discipline. Fourth, we provide examples of how lines of research in I-O psychology could usefully include the concept of capabilities via three hypothetical scenarios. Finally, we discuss key limitations to our methodology and assumption and conclude with an expression of our hope that this article assists in I-O psychology's conversation about the discipline's role in promoting social justice.

\section{From Handmaidens to Humanitarians?}

In 1960 Loren Baritz reviewed the history of industrial psychology in the United States in the book The Servants of Power and wrote the following memorable critique:

\footnotetext{
Many industrial social scientists have put themselves on auction. The power elites of America, especially the industrial elite, have bought their services-which, when applied to areas of relative power, have restricted the freedom of millions of workers. Time was when a man knew that his freedoms were being curtailed. Social scientists, however, are too sophisticated for that. The fires of pressure and control on a man are now kindled in his own thinking. Control need no longer be imposed. It can be encouraged to come from within. (pp. 209-210)
}

Over 50 years later, Milt Hakel, in the book Using Industrial-Organizational Psychology for the Greater Good: Helping Those Who Help Others, asked:

What should we make of the "servants of power" critique ...? The things we study no longer seem as simple as they appeared back then. Our domain has expanded, and our conceptualizations have expanded as well. It is our calling to be organizational scientists, engineers, and technologists, contributing and refining knowledge that can be applied for the greater good. (2013, p. 565)

We agree with Hakel (2013) and believe that I-O psychology has, in the spirit of Kornhauser (1930), begun to leave the "absurd situation" of serving as handmaidens to corporate/managerial interests (p. 433). This has been accomplished, in part, by researchers and practitioners who more readily adopt a broader array of priorities and values, and in another part, by managers who adopt a more diverse set of priorities and values (Porter \& Kramer, 2011). In terms of the broadening of I-O priorities and values, we need look no further than the pages of this journal where we have seen calls for, and meaningful discussions of, moving beyond just talking about justice (Greenberg, 2009; cf. Lefkowitz, 2009), adopting a person-centric view of work (Weiss \& Rupp, 2011; cf. Lefkowitz, 2011), considering how social responsibility can be integrated into core aspects of for-profit endeavors (Aguinis \& Glavas, 2013; cf. Rupp, Skarlicki, \& Shao, 2013), and how to go about addressing pressing social injustices (Ruggs et al., 2016; cf. Chatterjee, 2016). 
Despite our broad characterization of the field of I-O psychology as $\mathrm{POSH}$, we recognize both the long and diverse history of countless I-O psychologists who have devoted themselves and their careers to humanist concerns (e.g., Follett, 1919; Kanfer, 1999; Kanter, 1977; Kornhauser, 1965; Likert, 1967; Myers, 1929). We also recognize an array of voices in psychology from lower-income countries and regions that represent important exceptions to our characterization (e.g., Cooper, 2014; Hechanova, 2012; Marai, 2013; Martín-Baró, 1994; Mpofu, 2002; Oppong, 2013; Pandey, 2004). Furthermore, in our characterization of I-O psychology as POSH, we do not mean to imply that individual I-O psychologists come, necessarily, from POSH backgrounds or hold POSH sympathies but instead that the dominant narrative in the discipline holds a decidedly POSH bias.

Despite our optimism regarding the increasingly humanistic direction of I-O psychology, we are concerned that as the discipline addresses humanitarian concerns, its $\mathrm{POSH}$ bias might predispose it to unwitting harm. Our sense of concern arises due to the harm that can result from ostensibly wellmeaning efforts to help or understand marginalized populations (Easterly, 2006; Freire, 1970; Shouksmith, 1996; Trimble, Scharrón-del Río, \& Casillas, 2014). In psychology, serious mistakes have already been made by "blaming the victim"-specifically, attributing the situational causes of poverty to the characteristics and character of individuals (Carr \& MacLachlan, 1998; Misra \& Tripathi, 2004). Such a damaging attribution can come from either explicit or implicit signals; as an example of the latter, attributing the cause of poverty to an individual can happen through a disproportionate focus on individuals living in poverty and a neglect of the contextual factors that help to create poverty. Future mistakes could result from an uncritical awareness of the implicit values held by the discipline of I-O psychology (see Lefkowitz, 2003) and the strong power dynamics that exist in humanitarian aid and international development work (MacLachlan, Carr, \& McAuliffe, 2010).

Despite these concerns we believe that psychology, and in particular I$\mathrm{O}$ psychology, has much to add to humanitarian efforts (e.g., see a review by Carr et al., 2014). I-O psychology as a discipline is already helping to address salient humanitarian priorities as evidenced by such prominent developments as the Society of Industrial and Organizational Psychology (SIOP)'s establishment of consultative status with the United Nations (Scott, 2011), the adoption of the United Nations Global Compact by I-O psychology programs (Mallory et al., 2015), contributions made by I-O psychologists to a report by the United Nations Development Programme (UNDP, 2014) on the role of the private sector in poverty reduction, and the prominent role of an I-O psychologist in the development of an initiative to deliver evidence-based solutions to the United Nations Secretary General (United 
Nations, 2016). In addition, an international organization of I-O psychologists has been established expressly for the purpose of devoting the discipline to humanistic and humanitarian endeavors (www.gohwp.org; McWha et al., 2013). Active I-O psychologists in that group have contributed to at least five edited volumes on the subject since 2010 (Carr, MacLachlan, \& Furnham, 2012; MacLachlan, Carr, \& McCauliffe, 2010; McWha-Hermann, Maynard, \& O'Neill Berry, 2016; Olson-Buchanan, Koppes Bryan, \& Foster Thompson, 2013; Reichman, 2014). Chapters in those books have covered a range of topics, including entrepreneurship training in lower-income countries (Bischoff, Gielnik, \& Frese, 2014); the interrelationship of gender, work, and poverty (Schein, 2012); and the psychological health of humanitarian aid and development workers (Chuen Foo, 2016).

\section{The Poverty of a POSH Perspective}

I-O psychology's POSH perspective is composed of interrelated biases (Bergman \& Jean, 2016; Gelfand et al., 2008; Ruggs et al., 2013; Saxena et al., 2015) that have put the predominate focus of the discipline on people in the world who are able to escape the worst ravages of poverty. Similar biases have been observed in the psychological and behavioral sciences. Arnett (2008) made the case that American Psychological Association journals have been overwhelmingly focused on populations from relatively privileged sectors of the United States. Ryan and Gelfand (2012) assessed the international nature of I-O psychology via membership in professional associations, author associations, and the foci and samples of journal articles, broadly concluding that the discipline's international focus is limited. In addition, Henrich, Heine, and Norenzayan (2010) made the case that the behavioral sciences are overly focused on populations from Western, Educated, Industrialized, Rich, and Democratic (WEIRD) societies. Underscoring the problematic nature of a WEIRD bias, Henrich and colleagues (2010) cited evidence that behavioral phenomena-from visual perception and moral reasoning to the heritability of intelligence-differ meaningfully between WEIRD populations and other populations.

Below, we discuss and visualize how each dimension of I-O psychology's POSH bias relates to poverty. We do not mean to present evidence regarding I-O psychology's POSH bias per se, because this point has been made (Bergman \& Jean, 2016; Gelfand et al., 2008; Ruggs et al., 2013; Saxena et al., 2015); instead, we wish to illustrate how a POSH bias captures I-O psychology's neglect of the people most exposed to poverty. To accomplish this, we utilize the country level of analysis as a window on poverty. We must state at the outset that we believe that meaningful gradients of poverty exist on multiple levels of analysis. The POSH acronym highlights at least four levels, namely those of individuals in work units, economies, social groups, 
and countries (respectively). It is clear that poverty exists throughout the world, including in high-income countries (e.g., DeNavas-Walt \& Proctor, 2015), and even relative forms of poverty (as opposed to poverty defined by a fixed level of prosperity) are concerns for health and well-being (Wilkinson \& Pickett, 2006). However, as is clear by reviewing variability in human welfare around the world (see ILO, 2014; UNDP, 2015a; World Bank, 2012), substantial variability in poverty exists across countries. In addition, country names and nationalities are readily codifiable, and many indices of poverty are collected on country levels of analysis (UNDP, 2015b). To help overcome the limitations of using a country level of analysis, we rely predominately on intracountry indices (e.g., indices of intracountry inequality and the percentage of the population or workforce in a country affected by different forms of poverty).

To estimate the connection between a POSH bias and poverty, we measured the extent to which 142 countries featured in the United Nations Development Programme's Human Development Report (UNDP, 2015a) are represented in I-O psychology literature over the past 100 years (1917-2016). We then visually represent countries (Figures 1-4) according to their standing on aspects of poverty that are conceptually linked to one of the four POSH dimensions. We also represent each country by its share of the world population and whether the I-O literature overrepresents or underrepresents it in comparison to its share of the world's population (or alternatively, whether the country is not represented at all). A more detailed explanation of our methodology is included in the Appendix. We conceive of "representation" of a country in the I-O psychology literature broadly. We count all articles in which a country context or nationality is mentioned at least once in English (we excluded instances where prominent psychological professional associations and journals were mentioned, e.g., the American Psychological Association or the American Psychologist). Although previous analyses of a country bias have focused on such criteria as the origin of samples or the nationality of authorship (e.g., Mondo \& Kraut, 2010; Myers, 2016; Ryan \& Gelfand, 2012), we believe capturing all mentions of a country context or nationality helps to represent whether, and to what extent, the population in that country has been integrated into I-O psychology's dominant narrative (herein its perspective).

Out of the 142 countries in our analyses, 32 were categorized as "well represented"; these countries accounted for 1.04 billion people, or 14.36\% of the world's population in 2014. We categorized 99 countries as "underrepresented," and they accounted for 6.00 billion people $(82.87 \%$ of the world). Finally, there were 11 countries that were not represented in our searches, and they accounted for 104 million people (1.44\% of the world). We excluded from our categorization all microstates $(n=44)$, which we defined 


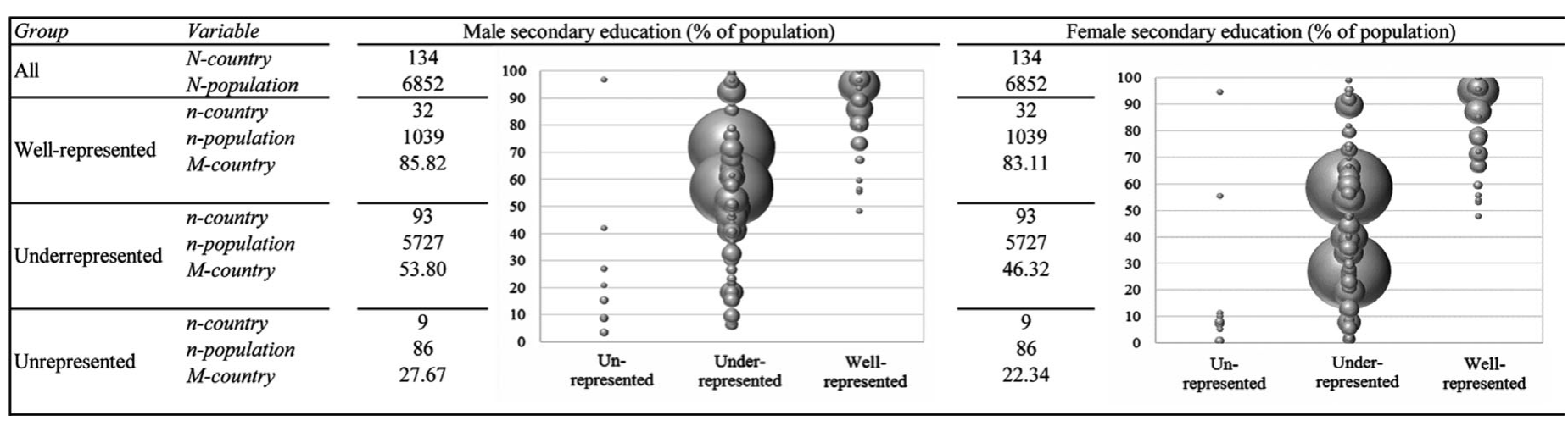

Figure 1. Example of the relationship of a professional bias to a bias away from poverty. Population figures are in millions of people. Figures feature countries represented according to (1) the percentage of men or women receiving a secondary education (ages 25-65); (2) whether the country's representation in I-O literature is greater (well-represented) or smaller (underrepresented) than the country's share of the world's population (if a country was not represented at all, it is categorized as unrepresented); and (3) the size of the country's population, which is reflected in the radius of the bubble reflecting that country. Next to each figure, the total country count ( $\mathrm{N}$-country), the total population covered ( $\mathrm{N}$-population), group country count ( $\mathrm{n}$-country), group population covered (n-population), and group country-level mean on the variable in question (M-country) are displayed. For more information about the methodology underlying these calculations, see the Appendix. All statistics are from UNDP (2015b). 


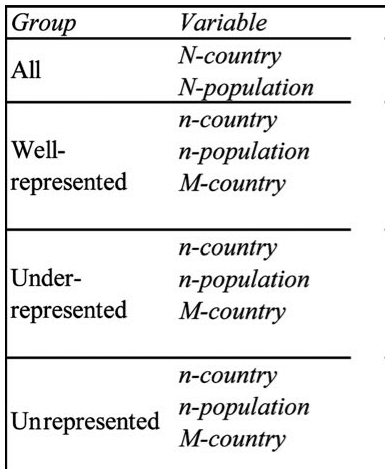

\begin{tabular}{cc} 
& $\mathrm{V}$ \\
49 \\
1379 \\
\hline 22 \\
453 \\
12.09 \\
\\
\hline 27 \\
927 \\
29.87 \\
\\
\hline 0 \\
0 \\
NA
\end{tabular}
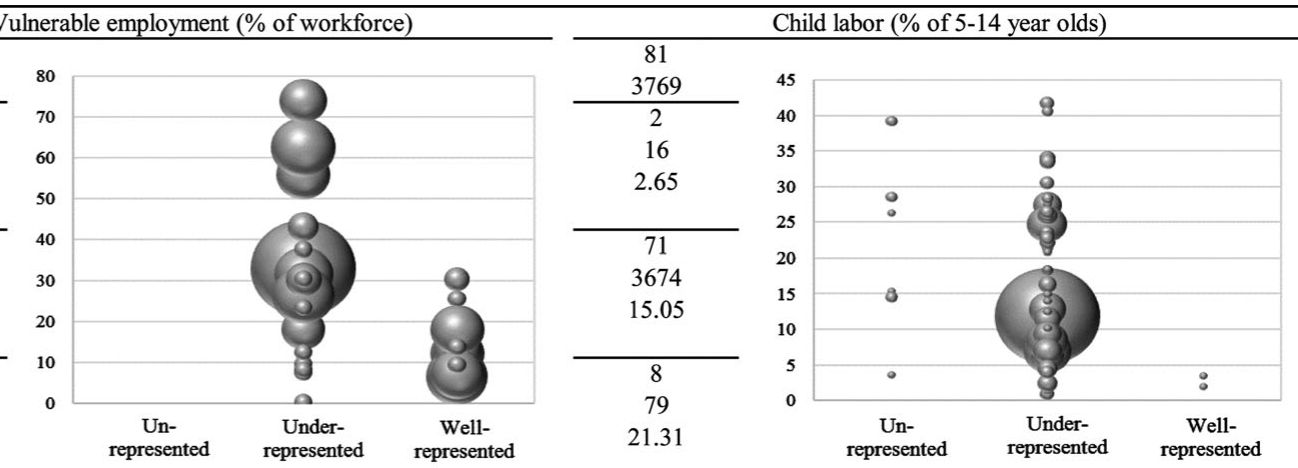

Figure 2. Example of the relationship of a bias toward official work in a formal economy with a bias away from poverty. Population figures are in millions of people. Figures feature countries represented according to (1) the percentage of the population in vulnerable employment (including own-account workers and unpaid family workers) or the percentage of 5-14-year-olds employed more than 1 hour per day; (2) whether the country's representation in I-O literature is greater (well-represented) or smaller (underrepresented) than the country's share of the world's population (if a country was not represented at all, it is categorized as unrepresented); and (3) the size of the country's population, which is reflected in the radius of the bubble reflecting that country. Next to each figure, the total country count ( $\mathrm{N}$-country), the total population covered ( $\mathrm{N}$-population), group country count ( $\mathrm{n}$-country), group population covered (n-population), and group country-level mean on the variable in question (M-country) are displayed. For more information about the methodology underlying these calculations, see the Appendix. All statistics are from UNDP (2015b). 


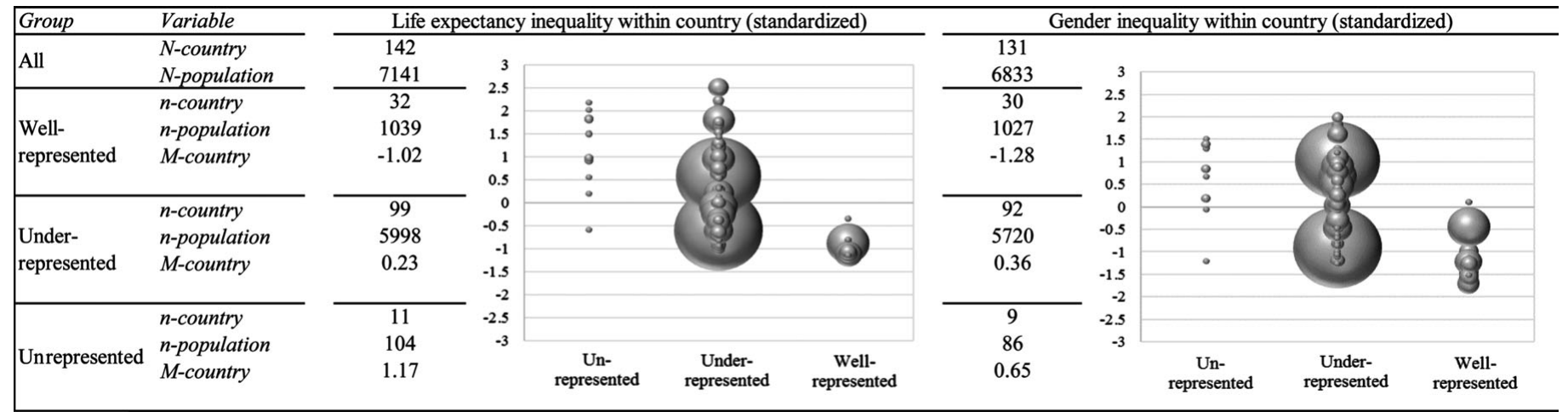

Figure 3. Example of the relationship of a bias toward groups that are relatively safe from discrimination with a bias away from poverty. Population figures are in millions of people. Figures feature countries represented according to (1) standardized values of life expectancy inequality within country (higher value $=$ greater inequality) or standardized values of gender inequality within country based on health, workforce participation, and empowerment (higher value = greater inequality); (2) whether the country's representation in I-O literature is greater (well-represented) or smaller (underrepresented) than the country's share of the world's population (if a country was not represented at all, it is categorized as unrepresented); and (3) the size of the country's population, which is reflected in the radius of the bubble reflecting that country. Next to each figure, the total country count ( $\mathrm{N}$-country), the total population covered ( $\mathrm{N}$-population), group country count ( -country), group population covered (n-population), and group country-level mean on the variable in question (M-country) are displayed. For more information about the methodology underlying these calculations, see the Appendix. All statistics are from UNDP (2015b). 


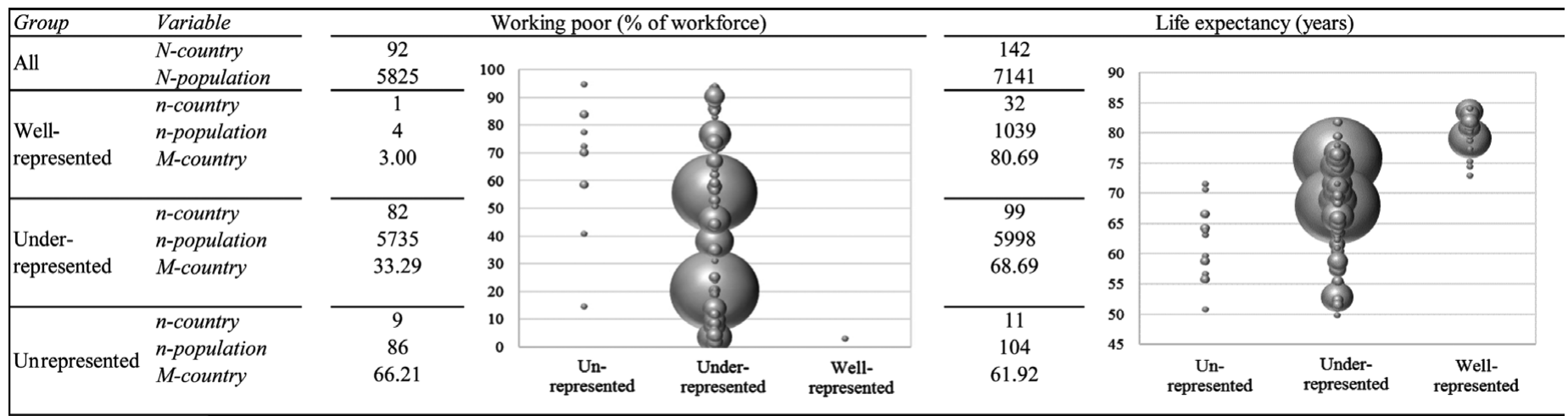

Figure 4. Example of the relationship of a bias toward high-income countries with a bias away from poverty. Population figures are in millions of people. Figures feature countries represented according to (1) the percentage of the workforce qualified as working poor (< $\$ 2 /$ day) or average life expectancy (in years); (2) whether the country's representation in I-O literature is greater (wellrepresented) or smaller (underrepresented) than the country's share of the world's population (if a country was not represented at all, it is categorized as unrepresented); and (3) the size of the country's population, which is reflected in the radius of the bubble reflecting that country. Next to each figure, the total country count ( $\mathrm{N}$-country), the total population covered ( $\mathrm{N}$-population), group country count (n-country), group population covered (n-population), group country-level mean (M-country), and group populationweighted mean (M-population) are displayed. For more information about the methodology underlying these calculations, see the Appendix. All statistics are from UNDP (2015b). 
as countries below 2 million people; together these countries accounted for 26.2 million people ( $0.36 \%$ of the world). Altogether the 142 countries included in our search accounted for 7.14 billion people or $98.62 \%$ of the estimated 7.24 billion people in the world in 2014 (UNDP, 2015b).

\section{Professionals}

Bergman and Jean (2016) have demonstrated that samples in I-O psychology overrepresent "professionals" (including managers, technicians, and salaried workers) in comparison to "workers" (including agricultural/fishery workers, craft/trade workers, and other low-skill personnel and wage earners). Being a professional comes with multiple protections from poverty. Professionals tend to earn more than workers and have a steadier income due to the higher prevalence of salaried versus wage-based work (Bergman \& Jean, 2016). Professionals tend to engage in forms of work that are not as physically taxing or dangerous (UNDP, 2015a). In addition, professionals tend to develop higher levels of human capital on the job (see Organization for Economic Cooperation and Development [OECD], 2013). We believe that the strongest connection between professionalization and poverty is that professionals tend to hold advanced and broad skills that they can leverage for financial capital in local and global markets. Consequently, the lack of a basic education sufficient to facilitate the development of such skills could be considered a manifestation of poverty (see Nussbaum, 2003; Sen, 1999). We are not arguing that workers without a professional status are inherently impoverished; instead, we are arguing that those without an education sufficient to support the realistic option of a professionalized job are impoverished. By focusing on professionals, I-O psychology tends not to include the perspective of people with such low levels of educational attainment/ opportunity.

As noted by Bergman and Jean (2016) and by Myers (2016), professionals tend to represent an even smaller percentage of the workforce in lowerincome countries. In parallel to this trend, a far smaller percentage of men, and especially women, tend to have attained more than a rudimentary level of education (which we define as less than a secondary level of education). As displayed in Figure 1, the countries that are relatively well-represented in I-O psychology have higher levels of secondary schooling $(85.82 \%$ for men, $83.11 \%$ for women) than unrepresented countries $(27.67 \%, 22.32 \%)$ and underrepresented countries (53.80\%, 46.32\%), which account for 5.73 billion people. Because of the importance of education to effective participation in society, a bias toward professionals contributes to a neglect of people who do not have the opportunity to participate in the wide range of career and social opportunities available to others in society. Therefore, according to our definition of poverty, which is based upon an individual's ability to 
effectively participate in society, a bias toward professionals appears to reflect an underlying neglect of people living in poverty.

\section{Official Work in a Formal Economy}

Saxena and colleagues (2015) describe the limited extent to which literature in I-O psychology has considered work in the informal economy. In line with the International Labor Organization's definition (ILO, 2013), we define work in the informal economy as activities that are not covered, or are insufficiently covered, by formal legal and political arrangements. Categories of work in the informal economy include members of informal producers' cooperatives, unpaid family workers, home-based producers, and casual wage workers. Being employed in the formal sector in an "official" or legally recognized job tends to be associated with a higher likelihood of protection from poverty due to the regular payment of wages, governmentally guaranteed social protections, formal labor contracts, and legal protections against discrimination (ILO, 2013). We are unaware of an empirical estimation of the extent to which I-O psychology research has considered formal versus informal economic contexts. This is perhaps not surprising given that data on informal work are limited (ILO, 2014). For example, country estimates of informal employment could only be obtained from the United Nations Development Programme (2015b) on 36 countries. Of these 36 countries, all have been either underrepresented or unrepresented in the I-O literature. To overcome data limitations on the informal economy, we utilized two measures to both estimate the extent to which I-O psychology might be biased toward formal versus informal work and to connect the idea of formality to poverty. In Figure 2, we utilize a measure of the extent to which people in a given country are in "vulnerable employment." This category includes both self-employed workers without full-time employees and unpaid family workers-groups that make up large shares of work in the informal economy (ILO, 2014). Among the 22 well-represented countries with available data, the average rate of vulnerable employment (as a share of the workforce) is $12.09 \%$. In contrast, it is $29.87 \%$ for the 27 underrepresented countries and extends to as high as $74 \%$ in Tanzania.

In addition to vulnerable employment, Figure 2 provides figures on child labor (defined as children between the ages of 5 and 14 years working more than 1 hour per day). Child labor takes place both legally and illegally throughout the world, often in the informal economy (UNDP, 2015a). The prevalence of child labor is strongly associated with poverty due to its tendency to interfere with children's educational, social, and physical development, and its tendency to greatly increase the risk that children will fall victim to physical injury or sexual exploitation (UNICEF, 2016). The average rate of child labor for the two well-represented countries with available 
statistics (Lebanon and Portugal) was $2.65 \%$. In contrast, the average rate is $15.05 \%$ for the 71 underrepresented countries with available data and $21.31 \%$ in unrepresented countries. The highest rate, in Cameroon, is $41.7 \%$.

In summary, a bias in I-O psychology toward formal work in the official economy indicates an omission of people from the I-O literature whose forms of working make them especially vulnerable to poverty.

\section{Safety from Discrimination}

Ruggs and colleagues (2013) argue that I-O psychology has missed an opportunity to understand and improve the welfare of marginalized groups that face a heightened risk of discrimination, including the LGBT community; the young and old; those with disabilities; and those facing discrimination due to their race, religion, weight, or marital status. Discrimination is closely related to poverty, as it is a powerful driver of social and economic exclusion from society (Dalal, 2010). Moreover, the negative effects of discrimination reverberate through generations (Umberson et al., 2017). The full extent to which I-O psychology has neglected consideration of populations that are susceptible to discrimination is not fully apparent until one looks across countries. The multifarious nature of discrimination can impact directly or indirectly upon discriminated populations in a variety of ways. We attempt to capture the overall impact of discrimination on different populations across countries by measuring intracountry inequality in life expectancy (UNDP, 2015b) - operating on the assumption that great inequality in life expectancy is likely to be due, at least in part, to forms of political, legal, social, or economic discrimination. Conversely, we reason that in countries with relatively high levels of equality in life expectancy, discrimination is on average likely to carry with it less severe consequences and/or to be less prevalent. Although there are multiple causes of inequalities in life expectancy, many of those causes (e.g., policies regarding taxation and healthcare) seem likely to be tied either directly or indirectly to stigma or bias toward a particular group (e.g., toward certain ethnicities, people with disabilities, or people living in poverty; see Singh \& Siahpush, 2006). As seen in Figure 3, countries that are well-represented in the I-O literature exhibit a low average level of inequality in life expectancy (-1.02, standardized). Indeed, all countries that are wellrepresented in I-O psychology have below-average levels of inequality in life expectancy. In contrast, underrepresented countries and unrepresented countries have higher average levels ( 0.23 and 1.17, respectively).

Perhaps the most prevalent form of discrimination in the world is discrimination tied to gender (UNDP, 2015a). To provide a picture of the extent of gender discrimination across countries, we again utilize a measure of intracountry inequality, this time based on factors relating to combined measures of female health, labor-market participation, and empowerment. 
As seen in Figure 3, 30 well-represented countries in I-O psychology exhibit below-average standardized values of gender inequality (-1.28). Only two well-represented countries (Kuwait and Lebanon) exhibit above-average levels of gender inequality, but their rates are relatively low $(0.11$ and 0.10 , respectively) compared to the highly populous and underrepresented country of India (1.03) and the underrepresented country with the highest overall rating on gender inequality: Yemen (1.98).

In summary, by analyzing statistics that we believe might indirectly and directly reflect discrimination (life expectancy inequality and gender inequality, respectively), we have worked to illustrate how much more prevalent discrimination is in countries outside of those that are well-represented in I-O psychology literature. Because of the close link between discrimination and exclusion from opportunities in society (Dalal, 2010), this trend is another way in which I-O psychology has not engaged with the people who are the most exposed to poverty.

\section{High-Income Countries}

Gelfand and colleagues (2008) argue that for organizational psychology to prosper, it needs to adopt a more global perspective. Although an important part of such a global perspective involves developing deeper insight into how culture affects phenomena in organizational psychology, Gelfand and colleagues (2008) also point out that I-O psychology is biased toward the perspective of relatively affluent nations with corresponding high levels of "human development" and "postmaterialist" values (see Inglehart \& Welzel, 2005; UNDP, 1990). Aggregate levels of income are often indicators of the prevalence of absolute levels of financial poverty. However, a low level of income in a country does not, necessarily, indicate a higher level of poverty. This point is illustrated in the debate over the appropriateness of measuring societal progress by way of overall happiness, as opposed to the more traditional measures of economic prosperity or growth (Helliwell, Layard, \& Sachs, 2012). Nevertheless, it appears that a good indication of poverty is the number of people who do not earn enough to sustain basic levels of health and well-being. Many such measures have been proposed (Alkire, 2010), but one that is particularly relevant to I-O psychology is the percentage of a country's active workforce who lives on wages below the threshold of $\$ 2$ per day-adjusted for purchasing power parity. These people are referred to as the "working poor." As can be seen in Figure 4, with only one exception (the State of Palestine at 3\%), data on the working poor are not available for countries that are well-represented in I-O psychology. In contrast, we can see that the vast majority of the world's population (at least 5.74 billion) lives in countries where, on average, over one-third of workers lives on less than $\$ 2$ per day. In the unrepresented country of Burundi, this figure is $94.80 \%$. 
With insufficient levels of income-often while actively employed-it can be difficult to acquire adequate nutrition, healthcare, and instruments of physical comfort and security (UNDP, 2015a). The net effect of such deprivation inevitably manifests in a country's life expectancy, preventing people from enjoying the numerous opportunities that are afforded to people who experience old age. As seen in Figure 4, the life expectancies for all countries that are well-represented in the I-O literature are at or above 72 years of age, with an average of 80.69 years. In contrast, the average life expectancy for populations in countries that are unrepresented in I-O psychology is 61.92 years of age. People in the underrepresented country of Lesotho hold an average life expectancy of 49.8 years. In summary, levels of economic and financial prosperity on a country level of analysis are linked to poverty, not only because such indices reflect variation in income but also because the conditions in those countries tend to constrain average life expectancies.

\section{The Problem of Poverty for Science and Practice}

We now turn to the reasons why a relative neglect of poverty is a problem for science and practice in I-O psychology. As before, we acknowledge and attempt to synthesize observations by previous commentators who have done an excellent job of reviewing problems associated with the various facets of I-O psychology's POSH bias (Bergman \& Jean, 2016; Gelfand et al., 2008; Green \& Dalal, 2016; Lefkowitz, 2016; Ruggs et al., 2013; Saxena et al., 2015). We divide this conversation into issues relating to research and practice. In terms of scientific concerns arising from a POSH bias, Bergman and Jean (2016) provided a useful framework for this discussion by highlighting how a bias in the discipline might lead to overlooking (a) phenomena that happen to workers, (b) differences in construct meaning, and (c) the moderation of known relationships.

Without further considering populations affected by poverty, I-O is unlikely to consider a range of important experiences and influences in the workplace and broader society that are operative for the vast majority of the world's population. Gradients of poverty help to reflect meaningful change in an individual's social ecology. Socioecological psychology has helped to highlight how objective contextual factors linked to poverty-like pathogen prevalence and climate degradation - work to shape psychological phenomena (Oishi, 2014). In particular, Van de Vliert (2013) made a case for the influence of climato-economic habitats on a range of psychobehavioral adaptations. For example, in relatively economically impoverished settings, Van de Vliert (2013) argues that existence needs are emphasized in contrast to growth needs, survival goals are emphasized in contrast to self-expression goals, and stressors might more readily lead to threat appraisals than to challenge appraisals. 
Due to differences in the types of needs, goals, and stressors between people living in poverty and those who do not, well-studied relationships or concepts in I-O psychology might not be as relevant in poverty-afflicted areas. As an illustration, consider the needs, goals, and stresses of a smallplot farmer in a lower-income country who relies on her crop both for the subsistence of her family and as a needs-based form of entrepreneurship. Questions of recruitment, selection, organizational development, and work attitudes like organizational commitment are probably not relevant to subsistence farming, at least in the same way as they are for professions in official jobs in higher-income countries. Moreover, a subsistence farmer's daily needs, goals, and stressors are likely to be meaningfully different than those commonly studied in I-O psychology. However, we assert that the benefits of research and practice in I-O psychology might be of as great, if not greater, benefit to impoverished workers than to large corporations. For example, I-O psychologists can assist in the effective design and delivery of information and communication technology (ICT) interventions for impoverished workers to help career and workforce development (Behrend, Gloss, \& Foster Thompson, 2013), design and support the training of nascent entrepreneurs in lower-income countries (Gielnik \& Frese, 2013), and help to understand and support the motivation of health workers who serve populations living in poverty (Meyer, Kanfer, \& Burrus, 2016).

It is also possible that the very meaning of variables among people living in poverty might be different than they are among people in contexts largely free from poverty. Perhaps the best example of this is an apparent difference in the meaning of financial success across gradients of poverty. In a comparison of the structure of goal content across 15 cultures, Grouzet and colleagues (2005) found that the goal of financial success was further from hedonism and closer to physical-safety goals in lower-income countries than in higher-income countries. Another example relates to the concept of discrimination. As highlighted by Gelfand and colleagues (2008), many contexts where I-O psychology have thrived enjoy relative freedom from pronounced warfare and social violence. Such forms of violence tend to predominate in lower-income settings with higher levels of inequality (Elgar $\&$ Aitken, 2011). Thus, between-group discrimination might carry different undertones for those people both living in poverty and affected by historical hatred and ethnic hostilities (Gelfand et al., 2008). Financial success and discrimination are just two concepts that might hold different meanings across gradients of poverty. Without appreciating these differences, I-O psychology might unwittingly misinterpret research findings or make recommendations that could be harmful to populations.

Not only might a POSH bias obscure certain phenomena or change the meaning of certain variables, but the moderating role of poverty might go 
underappreciated. In particular, based on both research and commentary in I-O psychology (Green \& Dalal, 2016; Meyer, Dalal, \& Bonaccio, 2009; Meyer, Dalal, \& Hermida, 2010) and scholarship from the field of development economics (Sen, 1999), we propose that gradients in poverty are likely to be associated with variation in the extent to which individual freedom is constrained by situations. Green and Dalal (2016) highlighted that professionals are likely to enjoy different levels of situational strength than other workers. Situational strength can be defined as implicit or explicit cues provided regarding the desirability of various forms of behavior (Meyer et al., 2010). As discussed by Meyer and colleagues (2010), situational strength can be divided into at least four dimensions: consistency, clarity, consequences, and constraints. In line with research on opportunity structures in the labor market and society that operate along socioeconomic gradients and provide salient constraints to behavior (Kreckel, 1980; Tickamyer \& Duncan, 1990), we reason that the "constraint" dimension of situational strength is likely to exhibit a positive relationship with contexts highly affected by poverty. Furthermore, we claim that this trend is likely tied to all dimensions of a POSH bias because variation in poverty can be observed along the levels of work units, economies, social groups, and countries. To help illustrate this connection, we briefly provide some empirical evidence and theoretical reasoning.

In terms of the relationship between situational constraints and professional work, we adopted an empirical approach and utilized a scale of situational constraints built by Meyer and colleagues (2009) that relies on data from the U.S. Department of Labor's Occupational Information Network ( $\mathrm{O}^{\star} \mathrm{NET}$; www.onetcenter.org). As a proxy for the professional nature of work, we utilized typical educational requirements in an occupation. We observed a substantial negative correlation $(r=-.61, n=689, p<.001)$ between educational requirements and occupational situational constraints in support of Green and Dalal (2016)'s reasoning that professionals (who predominate in occupations with higher levels of education) would hold occupations with lower levels of situational strength. When it comes to the connection between social discrimination and situational constraints, we note the close conceptual connection between exclusion from society due to discrimination and the reduction in available ways one might be freely able to participate in that society (Dalal, 2010). In contrast, a negative association between situational constraints and levels of income on a country level of analysis is broadly supported by findings regarding changing social norms across levels of socioeconomic development. In particular, as has been noted by Inglehart and Welzel (2005), higher levels of socioeconomic development are associated over time with increases in societal values for, and a greater incidence of, self-expression. In addition, it has also been observed that higher levels of discretionary income (owing to greater societal economic 
prosperity) facilitate a broader range of discretionary behavior (Sen, 1999). Furthermore, aggregate levels of income within a country are associated with greater economic complexity-complexity that allows for a broadening of potential behaviors both for individuals and for firms (see Hidalgo, Klinger, Barabási, \& Hausmann, 2007).

The relationship between poverty and situational constraints is relevant to I-O psychology because variation in situational strength has been shown to moderate relationships between individual differences and outcomes at work. For example, Meyer and colleagues (2009) noted that the relationship between conscientiousness and job performance is stronger in occupations with lower levels of situational strength. The moderating role of poverty is also likely relevant outside of an organizational context. For example, Blustein, Kenna, Gill, and DeVoy (2008) has observed that core theories of career development that assume a degree of individual agency (see Brown \& Lent, 2016) might be less relevant for those without access to education and other socioeconomic opportunities. As an additional example, the extent to which entrepreneurial behavior is driven by the psychological traits and states of individuals (Rauch \& Frese, 2007) might be limited in lower-income settings where more constricted needs-based forms of entrepreneurship abound (Estrin, Meyer, \& Bytchkova, 2006).

In terms of the problematic relationship between a POSH bias and professional practice, we observe that this bias is likely to limit I-O psychology's ability to intervene effectively in organizations and contexts that are highly affected by poverty. Research and practice can be connected in mutually beneficial ways under the right conditions (see Cascio, 2008), but even under such conditions, the relevance of I-O psychology could be limited by a mismatch in the context of research and the context of practice. A mismatch involving the implementation of research findings developed in contexts largely free of poverty but implemented in contexts affected by poverty might be particularly problematic for the future of practice of I-O psychology. Such a mismatch might lead to I-O psychology's tools being relatively less useful in settings with high levels of poverty, which also happen to be where the predominance of the world's economic growth is occurring. As seen in Figure 5, I-O psychology literature has underrepresented countries with higher average rates of economic growth (3.99\%) than well-represented countries (1.74\%). Furthermore, unrepresented countries exhibit the highest rates of growth at $4.22 \%$. Thus, emerging markets for I-O psychologists' employers and clients might be constrained by the discipline's POSH bias.

Contexts affected by poverty present opportunities for I-O psychology practice, both with for-profit organizations and also for humanitarian organizations. Indeed, the two categories are increasingly related. As discussed by the UNDP (2014) report on the role of the private sector 


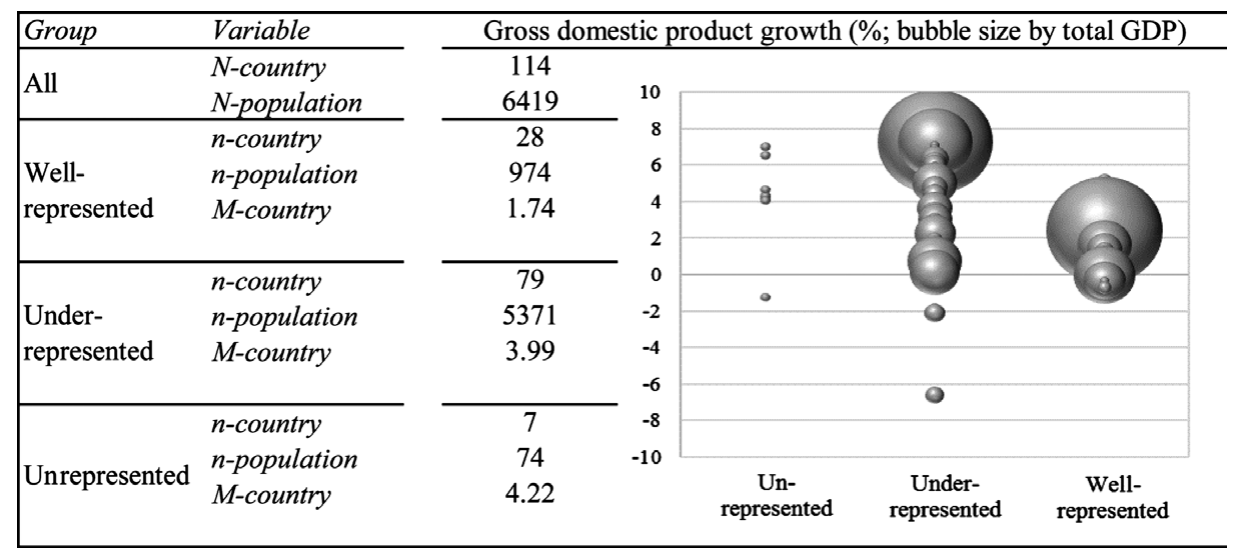

Figure 5. Example of the consequences of a POSH bias as it relates to economic growth. Population figures are in millions of people. Figures feature countries represented according to (1) growth in gross domestic product (GDP) in 2014 (UNDP, 2015b); (2) whether the country's representation in I-O literature is greater (well-represented) or smaller (underrepresented) than the country's share of the world's population (if a country was not represented at all, it is categorized as unrepresented; and (3) the size of the country's total GDP, which is reflected in the radius of the bubble reflecting that country. Next to each figure, the total country count (N-country), the total population covered ( $\mathrm{N}$-population), group country count ( $\mathrm{n}$-country), group population covered (n-population), group country-level mean (M-country), and group populationweighted mean (M-population) are displayed. For more information about the methodology underlying these calculations, see the Appendix. All statistics except those noted above are from UNDP (2015b).

in poverty reduction, two prominent methods of both social change and private-sector growth are social entrepreneurship, which utilizes for-profit means for prosocial aims and inclusive business, which includes people living in poverty as clients, customers, and/or employees. The UNDP report outlined a role for $\mathrm{I}-\mathrm{O}$ psychologist to better understand and accelerate these important drivers of social and economic prosperity through applied research-especially in the informal economy. However, the ability for I-O practitioners to seize the opportunity to engage with social entrepreneurship and inclusive business efforts in lower-income settings is likely contingent upon the discipline's greater engagement with the issue of poverty-and with those workers and organizations actively involved in the work of poverty reduction.

\section{The Case for Human Capabilities}

In the previous section, we made the case that I-O psychology's POSH bias reveals an underlying neglect of people and contexts affected by poverty. We 
also argued that this bias presents problems for I-O psychology's science and practice. However, we believe that the most compelling reason why I-O psychology should work to better understand poverty is the moral imperative to end it. In 2009, Greenberg made the case that I-O psychology should go beyond studying injustice by more readily intervening to promote justice in the world of work. Greenberg (2009) cited multiple reasons why interventions have not been more readily adopted, including that managers are unaware of justice problems, the "myth" of moral objectivity in applied science, the difficulty of intervening in organizational systems, and the belief that promoting justice will not help to advance theory. In response to Greenberg (2009), Lefkowitz (2009) further pointed out that I-O psychologists have produced relatively few interventions because consideration for distributive justice has to a certain extent been displaced by concerns for procedural justice, because the discipline's managerial bias discourages intervening on behalf of employees, and because organizational justice has been conceived of as a perceived phenomenon instead of an actual phenomenon. Lefkowitz (2009) concludes:

\footnotetext{
I am not suggesting that we abandon our training as scientists who aim to describe and explain human behavior. However, that enterprise doesn't preclude our also adopting moral positions that can be informed by our particular perspectives as psychologists and students of social organization. "But" you say, "that's not science, and anyway-whose notion of 'justice' should prevail?" To which I reply, "Yes, that's a good question. Welcome to the fray. Where have you been till now? There's lots to talk about." (p. 224)
}

We respond to Lefkowitz's (2009) dialectic by proposing a notion of justice that we believe is the right one to prevail as I-O psychology engages with humanitarian causes. We sidestep relitigating the debate over whether I-O psychology inevitably holds a particular set of values (it does; see: Lefkowitz, 2003), and instead we argue about what those values should be. We begin by stating "first principles" with which we assume that few if any I-O psychologists would disagree (but we hope to be corrected if this is not the case). The first principle is that everyone is born equally deserving of the same basic liberties as anyone else (Rawls, 2001). Second, social and economic inequalities should be to the greatest benefit of the least-advantaged members of society (Rawls, 2001). Third, all I-O psychologists, regardless of their nationality, are joined together by basic principles of professional conduct and responsibility to society (e.g., respect for the dignity of persons; see, e.g., International Union of Psychological Science, 2008). Fourth, I-O psychology as a discipline bestows benefits on segments of society via its science and practice (e.g., the development of relevant theories that can lead to greater understanding and the development of useful practical tools). According to these four principles, we would argue that I-O psychology's bias away from people living in poverty is unjust because it bestows disproportionate benefit on the most advantaged members of global society. 
Moreover, we assert that to correct this injustice, I-O psychologists around the world should collaborate with one another to concentrate the benefit of their science and practice on the people who are most disadvantaged: those living in multidimensional poverty. We are not claiming that all of the attention of I-O psychologists should be directed toward those living in poverty. Instead, we argue that the institutions that constitute the discipline (e.g., professional associations, journals, and graduate programs) have a moral duty to substantially reorient the field to understand and, where appropriate, intervene to address the needs of the least fortunate members of global society.

\section{The Capability Approach}

Better understanding and intervening to support the welfare of people living in the deepest forms of poverty is far easier said than done. There are significant obstacles to engaging with people affected by deep poverty and with humanitarian situations, as they might involve serious threats to physical safety, historic and deeply embedded traditions of injustice, and divergent and conflicting cultural norms (MacLachlan et al., 2010). In such situations, seemingly clear moral principles often become clouded, and the possibility of committing inadvertent harm through interventions and research becomes heightened (Bernal, Cumba-Avilés, \& RodriguezQuintana, 2014; OECD, 2009; Trimble et al., 2014). As both a moral guide and as an impetus for moral action, we propose that I-O psychology should consider the capability approach pioneered by Sen $(1992,1999,2009)$.

In explanation of the capability approach, Sen (1999) makes two defensible and yet seemingly contradictory observations: first, that justice-based interventions by one group on behalf of another are warranted in order to correct great inequities in society; and second, that due to the diversity in conceptualizations of justice that exist between different populations in the world, it is unjust for one group to impose its culturally value-laden conceptualization of justice on other populations. As evidence of the first observation we might cite the largely, but not entirely (BBC, 2006), extinct practice of Sati among Hindu communities in which a recently widowed woman, to some extent either voluntary or by force, burns to death on her husband's funeral pyre. Sen's (1999) general contention here is that such practices should not be justified by any cultural norms, and interventions to stop such practices are morally justified. In support of the second observation, we could reference any number of harmful if not fatal impositions of culture, either deliberate or accidental, by one population on another, including, for example, on the indigenous peoples in North America (Duran \& Duran, 1995). Sen $(1999,2009)$ claims that the right for one person or 
group to live according to their cultural norms is a fundamentally important human liberty.

The capability approach is geared to resolving, or at least providing tools to resolve, the apparent conflict between the above two observations. The approach is centered on the fundamental liberty for everyone to freely set, revise, and pursue their own conception of what is good and just (so long as that right does not impinge on the similar right of another). Sen (1999) argues in the book Development as Freedom that when presented with the opposing realities, that (a) injustices exist and need to be ended and that (b) doing so will inevitably involve imposing one's culturally based value propositions on others, the best way forward is to intervene up to, but not further than, the point at which the person whose welfare is being supported is actually free to decide his or her fate. The actual freedom to do something is labeled by Sen as a "capability." Therefore, the capability approach outlines an optimally just form of intervention into the lives and values of others. This optimized form of intervention prioritizes, and circumscribes, forms of assistance to those which promote individuals' capabilities.

As observed by Shrivastava, Jones, Selvarajah, and Van Gramberg (2016), the capability approach's handling of justice combines elements of both distributive and procedural justice (see Greenberg, 2009). The capability approach asserts that the full realization of procedural justice is contingent upon people having sufficient resources to participate meaningfully in societal processes. Sen (1999) points to at least three particularly important resources in this regard: basic levels of education, health, and income. Thus, resources like income are not good in and of themselves, but they are good because of their instrumental value in promoting capabilities. Thus, if we are attempting to ascertain whether a given intervention or project has benefitted the people it is meant to help, it is not enough to ask whether there have been objective increases in health, income, or education, but instead one must ascertain whether thanks to the intervention people are more free to live their lives in the manner of their choosing.

Organizational scholars including Giovanola (2009) and Renouard (2011) have utilized the capability approach to explore the ethics of business, employee relations, and corporate social responsibility. These explorations have, in general, proposed that the moral probity of business relations and activities should be judged by whether they support or impinge upon individual capabilities. Nussbaum (2003) has provided another conceptual bridge between the capability approach and the world of work by proposing a set of central human capabilities. This set includes a capability for people to exert a meaningful degree of control over their environment, which itself includes "having the rights to seek employment on an equal basis with others ... being 
Table 1. Fundamental Sets of Capabilities

\begin{tabular}{lc}
\hline \hline Sen (1999) & Nussbaum (2003, pp. 41-42) \\
\hline $\begin{array}{l}\text { Political freedoms } \\
\text { (e.g., civil rights) }\end{array}$ & 1. Life (e.g., a life of normal length) \\
Economic facilities (e.g., right to hold & 2. Bodily health (e.g., to be adaquately \\
property) & nourished) \\
Social opportunities & 3. Bodily integrity (e.g., to be safe from \\
(e.g., right to literacy and social & sexual assault) \\
discourse) & 4. Senses, imagination, and thought \\
Tranparency guarantees & (e.g., to be informed and adequately \\
(e.g., guarantees of disclosure) & educated) \\
& 5. Emotions (e.g., emotional \\
Protective security & development) \\
(e.g., social safety net) & 6. Practical reason (e.g., to form a \\
& conception of the good) \\
7. Affiliation (e.g., being able to live with & others) \\
8. Other species (e.g., being able to & experience nature) \\
9. Play (e.g., enjoying recreational & activities) \\
10. Control over one's environment \\
10a. Political control (e.g., the right of \\
free speech) \\
10b. Material control (e.g., seeking \\
employment on an equal basis as \\
others)
\end{tabular}

able to work as a human being, exercising practice reason, and entering into meaningful relationships of mutual recognition with other workers" (Nussbaum, 2003, p. 42). In addition, Sen (1999) has proposed five broad types of instrumental freedoms that are necessary for all capabilities, namely political freedoms (e.g., civil rights), economic facilities (e.g., the right to hold property), social opportunities (e.g., right to literacy in order to contribute to social discourse), transparency guarantees (e.g., guarantees of disclosure), and protective security (e.g. a social safety net). As examples of such "sets" of capabilities, we include lists from Nussbaum (2003) and Sen (1999) in Table 1.

\section{The Characteristics of Capabilities and Their Relevance to I-O Psychology}

Capabilities hold six notable characteristics (Alikire, 2005; Comim, 2008; Sen, 1999). First, capabilities are counterfactual; that is, they are the 
hypothetical opportunities and potential choices open to a given individual and cannot be fully appreciated by accounting for the choices that an individual actually makes. Second, capabilities are multidimensional-not only are there multiple fundamentally important capabilities, but one capability is not fungible or transferable in relation to another capability. Third, capabilities are differentially prioritized by each individual. Even if one set of capabilities applies to different people, it is likely that people will differentially order capabilities in terms of their relative importance. Fourth, capabilities are multivocal-the same capability might have substantially different meanings according to different people. Fifth, capabilities hold an element of objectivity. As detailed by Sen (1992), a chief concern in the capability approach is the "adaptive preference problem," wherein individuals' subjective self-report of capabilities is likely to be influenced by their relative position in society. Sixth, capabilities are fundamentally individualistic; despite the possibility of measuring capabilities on higher levels of analysis, the capabilities of individuals hold moral primacy. Sen (1999) has argued that capabilities need to be anchored to an individual to guard against the abrogation of fundamental individual rights by groups. Despite this individual-level focus, capabilities are also inherently concerned with group-level and social relations due to the fact that social opportunities are one of Sen's (1999) five instrumental freedoms.

Capabilities are usefully compared with two concepts that are more common in I-O psychology research: subjective well-being and empowerment. Subjective well-being, or the degree to which people indicate that their lives are desirable and proceeding well (Diener, Oishi, \& Lucas, 2015), is similar to the concept of capabilities in its focus on core aspects of individual welfare. Moreover, like capabilities, subjective well-being is often multidimensional and assessed on an individual level of analysis. However, capabilities appear to be more counterfactual and objective than subjective well-being, and capabilities tend to focus on particularistic evaluations (e.g., the capability to participate in civic affairs) as opposed to the more holistic evaluations of subjective well-being (e.g., of life satisfaction and positive affect). It appears possible to have a wide array of capabilities but to have a fundamental lack of subjective well-being (e.g., an adolescent with a great deal of opportunity in life but without major achievements necessary for life satisfaction or positive affect). Conversely, it appears possible to lack capabilities but to have high subjective well-being (for example, a person who is highly satisfied with what he or she perceives to be a wide range of opportunities, when in reality those opportunities are highly constrained by circumstance).

Capabilities are also similar to the concept of empowerment, particularly the combination of both sociostructural aspects of empowerment that deal with the actual possession of power and the psychological aspects of 
empowerment that involve the psychological states necessary for individuals to feel a sense of control (Spreitzer, 2008). When both sociostructural and psychological aspects of empowerment are intact for a given domain in life (e.g., in the development of one's own career), then one would appear to have capability in that domain. Without either the sociostructural or psychological aspects of empowerment, a capability would be limited. Thus, it is unlikely that a capability could consist of the power to accomplish something alongside ignorance of that power. Oppositely, without the power to accomplish something, belief in one's control over a situation falls short of being a capability. Thus, we might understand capabilities as a set of joint sociostructural and psychological forms of empowerment pertaining to particular areas of one's life. Capabilities are distinguishable from empowerment only in gradations; empowerment seems to be more general (e.g., I feel empowered), whereas capabilities are affixed to specific domains (e.g., I am capable of successfully engaging in political discourse but not capable of pursuing my career). The difference between capabilities and empowerment is slight enough that the capability approach has been seen as the moral justification for multidimensional empowerment (Bhattacharya \& Banerjee, 2012).

We see four predominate reasons why I-O psychologists should consider capabilities as a construct in research and practice. First, as the discipline increasingly engages with justice interventions, the capability approach provides a defensible moral guide for how to conduct such interventions. Second, capabilities are a more parsimonious way to conceptualize the combination of sociostructural and psychological empowerment-two concepts that are often considered separately (Maynard, Gilson, \& Mathieu, 2012). Third, capabilities are promising targets for theoretical development. As mentioned by Greenberg (2009), a reason why I-O psychologists have not more readily engaged in research-based justice interventions is because doing so is not rewarded by journals that prioritize theoretical development. Capabilities carry with them a rich and growing history of theoretical development relevant to organizational phenomena (Shrivastava et al., 2016). For example, there is a clear parallel between the moral importance of capabilities and the agentic theory of human development and behavior as proposed by Bandura (2006). In addition, the capability approach has been related to Ryan and Deci's (2000) theory of self-determination (Alkire, 2008). Indeed, Chirkov, Ryan, Kim, and Kaplan (2003) appear to claim that personal autonomy's relevance to human well-being across cultures is broadly supportive of Sen's (1999) thesis. Fourth, as I-O psychology engages with humanitarian concerns, the capability approach serves as a conceptual and methodological bridge to practices and research findings from the field of international development studies, which has a long history of considering the promise and peril of interventions to promote fundamental aspects 
of human welfare (Gloss \& Foster Thompson, 2013). Stakeholders in the field of international development have established a set of best practices for humanitarian work and assistance that are in keeping with the capability approach and can be readily adapted to guide research and interventions (OECD, 2009).

\section{Operationalizing Capabilities}

The better operationalization of capabilities has been identified as the most pressing challenge for the capability approach (Comim, 2008). Indeed, without operationalizing capabilities, their relevance and utility can be hard to grasp. The overall challenge of operationalizing capabilities can be broken down into two major tasks. The first task is to settle on a sufficiently flexible yet specific set of capabilities to consider. Two such sets were introduced in Table 1. In line with principles from the capability approach, the development of a list of relevant capabilities might combine a deductively derived list with another list of capabilities derived inductively. In this inductive process, a mixture of qualitative and quantitative methods might be used to ascertain individuals' relative prioritization of different capabilities and whether any important capabilities have been left out. As I-O psychology engages with the capability approach, there is an opportunity to incorporate empirically validated taxonomies of needs, values, and/or goals from psychology to help inform this effort (e.g., Grouzet et al., 2005; Ryan \& Deci, 2000; Schwartz, 1992). For example, Prilleltensky (2014) has suggested six fundamental facets of well-being relevant to justice and human development: interpersonal, communal, occupational, physical, psychological, and economic. Such a set could be empirically validated and tested. In addition, a set of fundamental capabilities might be generated that is specific to the world of work or to even more specific domains, such as capabilities for new employees or capabilities for the beneficiaries of corporate social responsibility (CSR) efforts.

The second major task in operationalizing capabilities is the development of a sufficiently simple and easy method for assessment. Although attempts have been made at the operationalization of capabilities into a straightforward survey (e.g., Lelli, 2008), the complex nature of capabilities has largely stymied attempts to establish a standardized measurement format (see Comim, Qizilabsh, \& Alkire, 2008). Attempts at the quantification of capabilities have often resorted to the measurement of resources that are known to support capabilities (e.g., income or healthcare). However, as discussed by Sen (1999), such resources are merely means to an end, and the end-an actual freedom-is not fully captured by the measurement of resources. In light of the characteristics of capabilities that present challenges to operationalization, we believe that there is considerable opportunity for 
I-O psychology to contribute to their reliable and valid measurement. There is a particular opportunity to help operationalize and measure capabilities within the context of work organizations (see Chopra \& Duraiappah, 2008).

The capability approach has been described as necessarily highly information-rich (Alkire, 2005). Practitioners have begun to utilize structural equation modeling (Bhattacharya \& Banerjee, 2012) and fuzzy sets theory (Kuklys, 2005) to deal with the challenges of capabilities' latent, multivocal, differentially weighted, and jointly objective and perceived nature. We similarly believe that tools like exploratory structural equation modeling (Asparouhov \& Muthen, 2009), latent profile analysis (Nylund, Asparouhov, \& Muthen, 2007), and multidimensional item response theory (Reckase, 2009) can help to overcome challenges inherent in the quantitative estimation of capabilities. In particular, these tools might come in handy when attempting to detect and account for any problems of "response shift," which I-O psychologists might classify as a problem of measurement equivalence (Tay, Meade, \& Cao, 2015).

Regardless as to how well capabilities are measured quantitatively, the priorities of the capability approach warrant an important role for methodological pluralism. Moreover, due to the subtle and complex nature of capabilities, qualitative methods appear warranted. Because of the capability approach's priority for individuals to define for themselves how to live their lives, research and interventions should be conducted in a participative and flexible manner that prioritizes the ownership and voice of those meant to be understood or benefited (Pistrang \& Barker, 2012). In particular, the participatory action research paradigm appears well suited to help explore and promote capabilities (Chesler, 1991). Such a flexible and participative approach appears most likely to help I-O psychologists to both maximize the validity of their conclusions and to avoid problems stemming from their discipline's historically POSH perspective (see Barker \& Pistrang, 2005).

\section{Putting Capabilities to Work: Illustrative Examples}

To add clarity to an idea of how capabilities might be applied to research and practice in I-O psychology, we briefly describe three lines of research and then introduce different fictional scenarios where the use of capabilities would be beneficial. To support these scenarios, we provide an example of how capabilities might be measured in Table 2. This example lists four capabilities that might emerge out of an initial investigatory process that combines the deductive inclusion of some capabilities from a literature review and the inductive inclusion of others from a set of semistructured interviews with community members. We stress that although we cite research leading up to each scenario, the scenarios we describe are entirely 
Table 2. Example of a Capability Set for Potential Use in I-O Psychology Research and Practice

\begin{tabular}{|c|c|c|c|}
\hline Capability & $\begin{array}{l}\text { Examples of } \\
\text { subjective/ } \\
\text { perceptual } \\
\text { indicators }\end{array}$ & $\begin{array}{l}\text { Examples of } \\
\text { objective/ } \\
\text { institutional } \\
\text { indicators }\end{array}$ & $\begin{array}{l}\text { Socioeconomic } \\
\text { covariates }\end{array}$ \\
\hline $\begin{array}{l}\text { Health and } \\
\text { physical } \\
\text { integrity }\end{array}$ & $\begin{array}{l}\text { Sense of personal } \\
\text { integrity } \\
\text { Perceived morbidity } \\
\text { Self-efficacy re: birth } \\
\text { control }\end{array}$ & $\begin{array}{l}\text { Caloric intake } \\
\text { Healthcare visits } \\
\text { Housing }\end{array}$ & \multirow{4}{*}{$\begin{array}{l}\text { Age, gender, sexual } \\
\text { orientation, religion, } \\
\text { caste, ethnicity, } \\
\text { marital status, } \\
\text { occupational status, } \\
\text { literacy, educational } \\
\text { attainment }\end{array}$} \\
\hline $\begin{array}{l}\text { Senses, } \\
\text { imagination, } \\
\text { and thought }\end{array}$ & $\begin{array}{l}\text { Intellectual stimulation } \\
\text { Trouble concentrating } \\
\text { Positive affect }\end{array}$ & $\begin{array}{l}\text { Access to reading } \\
\text { material } \\
\text { Frequency of reading } \\
\text { Difficulty level of } \\
\text { major life goals }\end{array}$ & \\
\hline Affiliation & $\begin{array}{l}\text { Self-efficacy regarding } \\
\text { establishing } \\
\text { friendships }\end{array}$ & $\begin{array}{l}\text { Leisure time } \\
\text { Participation in } \\
\text { community } \\
\text { activities } \\
\text { Social network size }\end{array}$ & \\
\hline $\begin{array}{l}\text { Material control } \\
\text { over one's } \\
\text { environment }\end{array}$ & $\begin{array}{l}\text { Job satisfaction } \\
\text { Self-efficacy regarding } \\
\text { job tasks } \\
\text { Self-efficacy regarding } \\
\text { career development }\end{array}$ & $\begin{array}{l}\text { Income level } \\
\text { Financial expenses } \\
\text { Need for major } \\
\text { personal household } \\
\text { items }\end{array}$ & \\
\hline
\end{tabular}

Note. This list of hypothetical capabilities and indicators is drawn from Bhattacharya and Banerjee (2012), Nussbaum (2003), Sen (1999).

fictitious and are simply meant to illustrate the potential utility of capabilities measurement.

\section{Living Wages}

Many people in vulnerable forms of employment are not protected by minimum wage legislation (World Bank, 2012). Even those who are protected by such legislation, such as some pickers in the tea industry in Malawi (Oxfam, 2014), are often unable to make ends meet because their country's legal minimum wages are insufficient to support basic needs (ILO, 2016). The concept of a "living wage" is commonly defined as the minimum income 
necessary for a worker and their household to meet their everyday aspirations for a decent quality of life. Yet many questions remain. For example, might there be an identifiable "tipping point" or "pivotal range" across working contexts where increases in wage rates do the most to benefit human capabilities (Carr, Parker, Arrowsmith, Watters, \& Jones, 2016)? This is the core question guiding a recently launched project, led by I-O psychologists, on the work psychology of decent work and living wages known as GLOW (Global Living Organizational Wage, 2017).

Scenario 1: Assessing the outcomes of a living wage intervention. Using the capabilities listed in Table 2, we might be able to test an intervention meant to determine the effects of introducing a living wage. By adopting a participatory action research paradigm and by casting our empirical net across all four capabilities, we might find that increases in wages are especially important at certain times of the year due to increases in home heating costs. Alternatively, we might also discover that the payment of wages in cash on the job site compromises the physical safety of women when they travel back home from the job site. The assessment of the effects of a living wage might also include the assessment of the capabilities of both immediate family and a random sampling of community members. Although there might be no noticeable benefits of a living wage to an employee, we might find that there are benefits to family members' health and affiliative capabilities.

\section{Organizational Inequality}

The world's current international development agenda has prioritized concepts such as shared prosperity and sustainable livelihoods (UN, 2016). These concepts imply a degree of equal opportunity both in the broader society and in the workplace. At the same time, organizations have been identified as one of the primary sites for the production of inequality in modern societies (Stainback, Tomaskovic-Devey, \& Skaggs, 2010). The issue of organizational inequality has been researched from a variety of perspectives. For example, Carr, McWha, MacLachlan, and Furnham (2010) explored the interpretations of pay differentials, referred to as "dual salaries," between expatriates and locals in a variety of organizational contexts. Moreover, McWha (2011) has explored the importance of inequality in income and power within the context of humanitarian and development organizations (see also Core Humanitarian Standard, 2017). Already, research in this vein has prompted a rethinking of approaches to pay salary discrepancies between expatriates and locals in multinational organizations (Carr, 2011), but many questions remain; for example, what are the long-term results of both objective and subjective pay inequality?

Scenario 2: Studying the effects of an organization's changes to pay. Measuring capabilities could help researchers to better understand the effects of 
changes in an organization's pay policies and the organization's level of pay inequality. After a company's preplanned change in certain pay rates, an investigation might discover that employees at the lower end of the organizational pay scale maintain relatively high levels of job satisfaction (a capability indicator in Table 2) before, during, and after the change. However, comparison of job satisfaction responses to indicators of capabilities might indicate a "response shift" in job satisfaction ratings among the employees from the lowest socioeconomic classes. This might call into question the reliance on job satisfaction scales in evaluating the effects of pay inequality at work. Without the inclusion of objective indicators and other capabilities, such a response shift might go unnoticed.

\section{The Impact of CSR on Capabilities}

Within the organizational sciences, a relatively large share of research has been devoted to understanding the effects of CSR on employees and organizational outcomes (Aguinis \& Glavas, 2012). As discussed by Rupp and Mallory (2015), consideration of the impact of CSR efforts on the stakeholders that such efforts are aimed at helping has been "all but abandoned to the shadows" (p. 226), and where it has been considered, dependent variables are usually econometric in nature. The measurement of capabilities provides an opportunity to more robustly consider the impact of CSR efforts on human well-being. In particular, as outlined in the UNDP's (2014) report on the relationship of the private sector to poverty reduction, the testing of best practices in internal and external CSR provides an opportunity for IO psychologists to experimentally manipulate key features of CSR efforts to determine their effects on the capabilities of members of the community. Best practices in aid and development efforts can help to inform practices in CSR. Moreover, these best practices tend to be broadly in line with principles from the capability approach. For example, the Paris Declaration on Aid Effectiveness (OECD, 2009) has emphasized the importance of an aid recipient's ownership of humanitarian projects.

Scenario 3: Guiding and evaluating a CSR effort. Both the capability approach and the measurement of capabilities could help to inform CSR efforts. The capabilities in Table 2 might be included in a pre- and postevaluation of a CSR effort in a lower-income community meant to deliver food, clothing, and household items to impoverished families. The managers responsible for the CSR effort might discover that the recipients of those goods were unexpectedly excluded from community activities after the CSR effort concluded. With some follow-up, it might be discovered that the recipients of the goods were ostracized from the community because community elders were not properly consulted and goods were not distributed to the neediest members of the community. According to both the principles of 
the capability approach and best-practices in humanitarian aid, the company running the CSR program might work with the community in a more participatory manner going forward to ensure that recipients, as well as members of their broader community, feel a sense of ownership over the project and have their capabilities enhanced to run their own community.

\section{The Role of Capabilities in I-O Research}

As is illustrated in the above three scenarios, the measurement of sets of capabilities has the benefit of providing a broad, information-rich, and multifaceted picture on human well-being. As reflected in the first scenario, although capabilities are measured on an individual level of analysis, they can and should be liberally assessed in the broader social networks of those people who are the intended beneficiaries of research or assistance. As indicated in the second scenario, the multifaceted and simultaneously objective and subjective nature of capabilities allows greater insight into response patterns and whether those patterns fully reflect an underlying capability. Finally, as illustrated in the third scenario, capabilities and the principles of the capability approach might help to inform the processes of humanitarian assistance and research with people living in poverty.

\section{Limitations}

This article's characterization of I-O psychology's POSH bias has limitations. Despite poverty existing on multiple levels of analysis, we were restricted to utilizing a predominately country level of analysis to characterize I-O psychology's perspective. This reliance on a country level of analysis likely underestimates the extent to which I-O psychology has focused on POSH priorities because, due to a tendency to overrepresent professionals, workers in the formal economy, and populations not affected by great discrimination, some of the people least affected by poverty in lower-income countries are likely studied when studies are conducted in those countries. Another limitation of our estimation of a POSH bias is that our search criteria relied on the explicit mention of a country context in English characters. It is possible that subnational regions or supranational regions were considered at different rates than the national rates we observed. Moreover, it is possible that anomalies in the trivial use of country names has meaningfully distorted our results. Although this is a possibility, we judge it to be an unlikely one in light of the high reliability observed among our three searches $(\alpha=.91)$. Finally, our searches were limited to the 23 academic journals listed by Zickar and Highhouse (2001), which excludes books, conference proceedings, and the content of other journals in which I-O psychologists might regularly publish.

Beyond methodological limitations, this article's emphasis on the importance of capabilities also carries limitations. First, in extreme conditions, it is 
certainly possible to overemphasize the importance of freedom, as discussed by Schwartz (2000). Second, the capability approach has been criticized for its emphasis on the individual as a level of analysis and on the moral primacy of individual liberty. We believe that this is an inherent limitation of the approach, but we agree with Sen (1999) that this is the best of any alternative because it protects against the abrogation of the liberties of vulnerable individuals from powerful individuals and groups. Third, we neglected to parse the extent to which climatic variables either exacerbate or mollify various effects of poverty on capabilities. As argued by Van de Vliert (2013), the influence of climate can be substantial in this regard. Finally, this article is limited in its scope because it has excluded robust discussions of why I$\mathrm{O}$ psychology holds such a POSH perspective and what I-O psychologists can practically do to correct it. We avoided focusing on these topics because they have been handled well elsewhere (e.g., Bergman \& Jean, 2016; Koppes, 2007; Lefkowitz, 2016; McWha, Mji, MacLachlan, \& Carr, 2014).

\section{Conclusion}

As we mentioned at the beginning of our article, in 1960 Baritz provided a stinging critique of industrial social scientists for having helped to "restrict the freedom of millions of workers" (p. 209). Despite a decidedly POSH perspective over the past 100 years, we believe that I-O psychology has begun to emerge from the shadow of such characterizations thanks to the gradual but continual broadening of the field to include more humanistic and humanitarian concerns. We hope that our arguments help to make a case for why a focus on promoting the freedoms, that is, the capabilities, of people living in the deepest forms of poverty is not only good for science and practice but also an attainable moral imperative. Finally, we hope that this article will generate discussion regarding what notion of justice should guide I-O psychology's scientist-practitioner-humanist model because, as suggested by Lefkowitz (2009), there is a lot yet to talk about.

\section{References}

Aguinis, H., \& Glavas, A. (2012). What we know and don't know about corporate social responsibility: A review and research agenda. Journal of Management, 38(4), 932-968.

Aguinis, H., \& Glavas, A. (2013). Embedded versus peripheral corporate social responsibility: Psychological foundations. Industrial and Organizational Psychology, 6(4), 314-332.

Alkire, S. (2005). Why the capability approach? Journal of Human Development, 6(1), 115-135.

Alkire, S. (2008). Choosing dimensions: The capability approach and multidimensional poverty (MPRA Paper No. 8862). Retrieved from mpra.ub.uni-muenchen.de/8862/

Alkire, S. (2010). Human development: Definitions, critiques, and related concepts (Human development research paper 2010/01). Retrieved from www.undp.org

American Psychological Association. (2017). PsycInfo: About the database. Retrieved from http://www. apa.org/pubs/databases/psycinfo/ 
Arnett, J. J. (2008). The neglected 95\%: Why American psychology needs to become less American. American Psychologist, 63(7), 602-614.

Asparouhov, T., \& Muthén, B. (2009). Exploratory structural equation modeling. Structural Equation Modeling: A Multidisciplinary Journal, 16(3), 397-438.

Bandura, A. (2006). Toward a psychology of human agency. Perspectives on Psychological Science, 1(2), $164-180$.

Baritz, L. (1960). The servants of power: A history of the use of social science in American industry. Middletown, CT: Wesleyan University Press.

Barker, C., \& Pistrang, N. (2005). Quality criteria under methodological pluralism: Implications for conducting and evaluating research. American Journal of Community Psychology, 35(3-4), 201212.

BBC (British Broadcasting Corporation). (2006, August 22). India wife dies on husband's pyre. Retrieved from news.bbc.co.uk.

Behrend, T. S., Gloss, A. E., \& Foster Thompson, L. (2013). Global development through the psychology of workplace technology. In M. D. Coovert, \& L. Foster Thompson (Eds.), The psychology of workplace technology (pp. 261-283). New York: Routledge Academic.

Bergman, M. E., \& Jean, V. A. (2016). Where have all the "workers" gone? A critical analysis of the unrepresentativeness of our samples relative to the labor market in the industrial-organizational psychology literature. Industrial and Organizational Psychology, 9(1), 84-113.

Bernal, G., Cumba-Avilés, E., \& Rodriguez-Quintana, N. (2014). Methodological challenges in research with ethnic, racial, and ethnocultural groups. In L. Comas-Diaz (Ed.), APA handbook of multicultural psychology (Vol. 1): Theory and research (pp. 105-123). Washington, DC: American Psychological Association.

Bhattacharya, J., \& Banerjee, S. (2012). Women empowerment as multidimensional capability enhancement: An application of structural equation modeling. Poverty \& Public Policy, 4(3), 79-98.

Bischoff, K. M., Gielnik, M. M., \& Frese, M. (2014). Entrepreneurship training in developing countries. In J. B. Olson-Buchanan, L. L. Koppes Bryan, \& L. Foster Thompson (Eds.), Using industrialorganizational psychology for the greater good: Helping those who help others (pp. 92-119). New York: Routledge.

Blustein, D. L., Kenna, A. C., Gill, N., \& DeVoy, J. E. (2008). The psychology of working: A new framework for counseling practice and public policy. The Career Development Quarterly, 56(4), 294308.

Brown, S. D., \& Lent, R. W. (2016). Vocational psychology: Agency, equity, and well-being. Annual Review of Psychology, 67, 541-565.

Carr, S. C. (2011). Discrepancies in aid and development workers' salaries (Impact Case Study). Swindon, UK: Economic \& Social Research Council.

Carr, S. C., \& Maclachlan, M. (1998). Psychology in developing countries: Reassessing its impact. Psychology \& Developing Societies, 10(1), 1-20.

Carr, S. C., MacLachlan, M., \& Furnham, A. (Eds.). (2012). Humanitarian work psychology. London: Palgrave Macmillan.

Carr, S. C., McWha, I., MacLachlan, M., \& Furnham, A. (2010). International-local remuneration differences across six countries: Do they undermine poverty reduction work? International Journal of Psychology, 45(5), 321-340.

Carr, S. C., Parker, J., Arrowsmith, J., Watters, P. A., \& Jones, H. (2016). Can a "living wage" springboard human capability? An exploratory study from New Zealand. Labour \& Industry, 26, 24-39.

Carr, S. C., Thompson, M., Dalal, A. K., de Guzman, J. M., Gloss, A., Munns, L., \& Steadman, A. (2014). Psychology and poverty reduction: A global special issue. International Perspectives in Psychology: Research, Practice, Consultation, 3(4), 215-237.

Cascio, W. F. (2008). To prosper, organizational psychology should ... bridge application and scholarship. Journal of Organizational Behavior, 29, 455-468.

Chatterjee, D. (2016). Approaching "Baltimore is burning" from a systems change perspective: Role of I-O psychologists as change agents. Industrial and Organizational Psychology, 9(3), 565-572. 
Chesler, M. A. (1991). Participatory action research with self-help groups: An alternative paradigm for inquiry and action. American Journal of Community Psychology, 19(5), 757-768.

Chirkov, V., Ryan, R. M., Kim, Y., \& Kaplan, U. (2003). Differentiating autonomy from individualism and independence: A self-determination theory perspective on internalization of cultural orientations and well-being. Journal of Personality and Social Psychology, 84(1), 97-110.

Chopra, K., \& Duraiappah, A. K. (2008). Operationalizing capabilities and freedom in a segmented society: The role of institutions. In F. Comim, M. Qizilbash, \& S. Alkire (Eds.), The capability approach: Concepts, measures and applications. Cambridge, UK: Cambridge University Press.

Chuen Foo, S. (2016). Catch-22 in humanitarian and development work: Emotional exhaustion, withdrawal, health, and work motives of these workers. In I. McWha-Hermann, D. C. Maynard, \& M. O'Neill Berry (Eds.), Humanitarian work psychology and the global development agenda: Case studies and interventions (pp. 113-126). London: Routledge.

Comim, F. (2008). Measuring capabilities. In F. Comim, M. Qizilbash, \& S. Alkire (Eds.), The capability approach: Concepts, measures and applications (pp. 157-200). Cambridge, UK: Cambridge University Press.

Comim, F., Qizilbash, M., \& Alkire, S. (Eds.). (2008). The capability approach: Concepts, measures and applications. Cambridge, UK: Cambridge University Press.

Cooper, S. (2014). A synopsis of South African psychology from apartheid to democracy. American Psychologist, 69(8), 837-847.

Core Humanitarian Standard. (2017). Core humanitarian standard alliance. Retrieved from http:// www.chsalliance.org/news/blog/fair-pay

Dalal, A. K. (2010). Disability-poverty nexus: Psycho-social impediments to participatory development. Psychology \& Developing Societies, 22(2), 409-437.

DeNavas-Walt, C., \& Proctor, B. D. (2015). Income poverty in the United States: 2014 (Current Population Reports). United States Census Bureau. Retrieved from www.census.gov

Diener, E., Oishi, S., \& Lucas, R. E. (2015). National accounts of subjective well-being. American Psychologist, 70(3), 234-242.

Duran, E., \& Duran, B. (1995). Native American postcolonial psychology. Albany, NY: SUNY Press.

Easterly, W. (2006). White man's burden: Why the West's efforts to aid the rest have done so much ill and so much good. New York: Penguin Press.

Elgar, F. J., \& Aitken, N. (2011). Income inequality, trust and homicide in 33 countries. The European Journal of Public Health, 21(2), 241-246.

Estrin, S., Meyer, K. E. \& Bytchkova, M. (2006). Entrepreneurship in transition economies. In M. C. Casson, B. Yeung, A. Basu, \& N. Wadeson (Eds.), The Oxford handbook of entrepreneurship (pp. 693-725). Oxford, UK: Oxford University Press.

Follett, M. P. (1919). Community is a process. The Philosophical Review, XXVIII, 576-588.

Freire, P. (1970). Pedagogy of the oppressed. New York: Continuum.

Gelfand, M. J., Leslie, L. M., \& Fehr, R. (2008). To prosper, organizational psychology should ... adopt a global perspective. Journal of Organizational Behavior, 29(4), 493-517.

Gielnik, M. M., \& Frese, M. (2013). Entrepreneurship and poverty reduction: Applying I-O psychology to microbusiness and entrepreneurship in developing countries. In J. B. Olson-Buchanan, L. L. Koppes Bryan, \& L. Foster Thompson (Eds.), Using industrial-organizational psychology for the greater good: Helping those who help others (pp. 394-423). New York: Routledge.

Giovanola, B. (2009). Re-thinking the anthropological and ethical foundation of economics and business: Human richness and capabilities enhancement. Journal of Business Ethics, 88(3), 431-444.

Gloss, A., \& Foster Thompson, L. (2013). I-O psychology without borders: The emergence of humanitarian work psychology. In J. B. Olson-Buchanan, L. L. Koppes Bryan, \& L. F. Thompson (Eds.), Using I-O psychology for the greater good: Helping those who help others (pp. 393-394). New York: Routledge Academic.

GLOW (Global Living Organizational Wage). (2017). Project GLOW. Retrieved from http://www. massey.ac.nz/project-glow 
Green, J. P., \& Dalal, R. S. (2016). How journals can facilitate the study of underlying situational characteristics distinguishing worker and professional samples. Industrial and Organizational Psychology, 9(1), 121-129.

Greenberg, J. (2009). Everybody talks about organizational justice, but nobody does anything about it. Industrial and Organizational Psychology, 2(2), 181-195.

Grouzet, F. M. E., Kasser, T., Ahuvia, A., Dols, J. M. F., Kim, Y., Lau, S., ... Sheldon, K. M. (2005). The structure of goal contents across 15 cultures. Journal of Personality and Social Psychology, 89(5), 800-816.

Hakel, M. (2013). Homo economicus, industrial psychology, and the greater good. In J. B. OlsonBuchanan, L. L. Koppes Bryan, \& L. Foster Thompson (Eds.), Using industrial-organizational psychology for the greater good: Helping those who help others (pp. 559-566). New York: Routledge.

Hechanova, R. M. (2012). Developing industrial-organizational psychology in a developing country: The Philippine experience (In L. Foster, A. Gloss, \& M. K. Ward [Eds.]., Spotlight on Humanitarian Work Psychology). Industrial Organizational Psychologist, 50(2), 91-96.

Helliwell, J., Layard, R., \& Sachs, J. (Eds.). (2012). World happiness report. Retrieved from www.earth. columbia.edu

Henrich, J., Heine, S. J., \& Norenzayan, A. (2010). The weirdest people in the world? Behavioral and Brain Sciences, 33(2-3), 61-83.

Hidalgo, C. A., Klinger, B., Barabási, A. L., \& Hausmann, R. (2007). The product space conditions the development of nations. Science, 317(5837), 482-487.

ILO (International Labour Organization). (2013). The informal economy and decent work: A policy resource guide supporting transition to formality. Retrieved from www.ilo.org.

ILO (International Labour Organization). (2014). World of work report 2014: Developing with jobs. Retrieved from www.ilo.org.

ILO (International Labour Organization). (2016). World employment and social outlook 2016: Transforming jobs to end poverty. Retrieved from www.ilo.org.

International Union of Psychological Science (2008). Universal Declaration of Ethical Principles for Psychologists. Retrieved from http://www.iupsys.net/.

Inglehart, R., \& Welzel, C. (2005). Modernization, cultural change, and democracy: The human development sequence. Cambridge, UK: Cambridge University Press.

Kanfer, R. (1999). Measuring health worker motivation in developing countries (Major Applied Research-Working Paper 1). Bethesda, MD: Partnerships for Health Reform.

Kanter, R. M. (1977). Work and family in the United States: A critical review and agenda for research and policy. New York: Russell Sage Foundation.

Koppes, L. L. (Ed.). (2007). Historical perspectives in industrial and organizational psychology. Mahwah, NJ: Lawrence Erlbaum.

Kornhauser, A. W. (1930). Industrial psychology in England, Germany and the United States. Personnel Journal, 8(6), 421-434.

Kornhauser, A. W. (1965). Mental health of the industrial worker: A Detroit study. Oxford, UK: John Wiley.

Kreckel, R. (1980). Unequal opportunity structure and labour market segmentation. Sociology, 14(4), 525-550.

Kuklys, W. (2005). Amartya Sen's capability approach: Theoretical insights and empirical applications. Berlin: Springer Science \& Business Media.

Lefkowitz, J. (1990). The scientist-practitioner model is not enough. The Industrial-Organizational Psychologist, 28(1), 47-51.

Lefkowitz, J. (2003). Ethics and values in industrial-organizational psychology. Mahwah, NJ: Lawrence Erlbaum.

Lefkowitz, J. (2009). Promoting employee justice: It's even worse than that. Industrial and Organizational Psychology, 2(2), 221-225.

Lefkowitz, J. (2011). The science, practice, and morality of work psychology. Industrial and Organizational Psychology, 4(1), 112-115. 
Lefkowitz, J. (2016). News flash! Work psychology discovers workers! Industrial and Organizational Psychology, 9(1), 137-144.

Lelli, S. (2008). Operationalising Sen's capability approach: The influence of the selected technique. In F. Comim, M. Qizilbash, \& S. Alkire (Eds.), The capability approach: Concepts, measures and applications (pp. 310-361). Cambridge, UK: Cambridge University Press.

Likert, R. (1967). The human organization: Its management and values. New York: McGraw-Hill.

MacLachlan, M., Carr, S. C., \& McAuliffe, E. (2010). The aid triangle: Recognizing the human dynamics of dominance, justice and identity. London: Fernwood.

Mallory, D., Rupp, D. E., Scott, J. C., Saari, L., Foster, L., Osicki, M., \& Sall, E. (2015). Attention all I-O programs: It's time to join the United Nations Global Compact! The Industrial-Organizational Psychologist, 52(4), 135-136.

Marai, L. (2013). Industrial-organizational psychology in Papua New Guinea (In L. Foster, A. Gloss, \& M. K. Ward [Eds.]., Spotlight on Humanitarian Work Psychology). Industrial Organizational Psychologist, 50(4), 111-114.

Martín-Baró, I. (1994). Writings for a liberation psychology. Cambridge, MA: Harvard University Press.

Maynard, M. T., Gilson, L. L., \& Mathieu, J. E. (2012). Empowerment-fad or fab? A multilevel review of the past two decades of research. Journal of Management, 38(4), 1231-1281.

McWha, I. (2011). The roles of, and relationships between, expatriates, volunteers, and local development workers. Development in Practice, 21(1), 29-40.

McWha, I., Gloss, A. E., Godbout, J., Marai, L., Abdul-Nasiru, I., Foster, L., \& Berry, M. O. (2013). Humanitarian work psychology: An emerging community of practice in I-O psychology. CrossCultural Psychology Bulletin, 45-46, 6-15.

McWha, I., Mji, G., MacLachlan, M., \& Carr, S. C. (2014). Challenges and opportunities to developing South-North program partnerships. In R. L. Griffith, L. F. Thompson, \& B. K. Armon (Eds.), Internationalizing the curriculum in organizational psychology (pp. 17-40). New York: Springer.

McWha-Hermann, I., Maynard, D. C., \& Berry, M. O. N. (Eds.). (2016). Humanitarian work psychology and the global development agenda: Case studies and interventions. London: Routledge.

Meyer, R. D., Dalal, R. S., \& Bonaccio, S. (2009). A meta-analytic investigation into the moderating effects of situational strength on the conscientiousness-performance relationship. Journal of Organizational Behavior, 30(8), 1077-1102.

Meyer, R. D., Dalal, R. S., \& Hermida, R. (2010). A review and synthesis of situational strength in the organizational sciences. Journal of Management, 36(1), 121-140.

Meyer, R. D., Kanfer, R., \& Burrus, C. (2016). Improving motivation and performance among frontline healthcare workers in rural India: The role of team-based goals and incentives. In I. McWha-Hermann, D. C. Maynard, \& M. O’Neill Berry (Eds.), Humanitarian work psychology and the global development agenda: Case studies and interventions (pp. 100-112). London: Routledge.

Misra, G., \& Tripathi, K. N. (2004). Psychological dimensions of poverty and deprivation. In J. Pandey (Ed.), Psychology in India revisited: Developments in the discipline, Volume 3: Applied social and organizational psychology (pp. 118-215). New Delhi, India: Sage.

Mondo, L. J., \& Kraut, A. I. (2010). Does globalization change I-O research? Not that much, so far. The Industrial-Organizational Psychologist, 47(4), 45-50.

Mpofu, E. (2002). Psychology in sub-Saharan Africa: Challenges, prospects and promises. International Journal of Psychology, 37(3), 179-186.

Myers, C. S. (1929). Industrial psychology. London: Thornton Butterworth.

Myers, C. G. (2016). Where in the world are the workers? Cultural underrepresentation in I-O research. Industrial and Organizational Psychology, 9(1), 144-152.

Nussbaum, M. (2003). Capabilities as fundamental entitlements: Sen and social justice. Feminist Economics, 9(2-3), 33-59.

Nylund, K. L., Asparouhov, T., \& Muthén, B. O. (2007). Deciding on the number of classes in latent class analysis and growth mixture modeling: A Monte Carlo simulation study. Structural Equation Modeling, 14(4), 535-569. 
OECD (Organizational for Economic Cooperation and Development). (2009). Better aid: Aid effectiveness-a progress report on implementing the Paris Declaration. Retrieved from www.oecd. org

OECD (Organizational for Economic Cooperation and Development). (2013). OECD Skills Outlook: First results from the survey of adult skills. Retrieved from www.oecd.org.

Oishi, S. (2014). Socioecological psychology. Annual Review of Psychology, 65, 581-609.

Olson-Buchanan, J. B., Koppes-Bryan, L. L., \& Foster Thompson, L. (Eds.). (2013). Using industrialorganizational psychology for the greater good: Helping those who help others. New York: Routledge.

Oppong, S. (2013). Industrial-organizational psychology in Ghana (In L. Foster, A. Gloss, \& M. K. Ward [Eds.]., Spotlight on Humanitarian Work Psychology). Industrial Organizational Psychologist, 50(3), 79-83.

Oxfam. (2014). Steps towards a living wage in global supply chains. Oxfam Issue Briefing. Cowley, UK: Oxfam GB.

Pandey, J. (Ed.). (2004). Psychology in India revisited: Developments in the discipline, Volume 3: Applied social and organizational psychology. New Delhi, India: Sage.

Pistrang, N., \& Barker, C. (2012). Varieties of qualitative research: A pragmatic approach to selecting methods. In H. Cooper, P. M. Camic, D. L. Long, A. T. Panter, D. Rindskopf, \& K. Sher (Eds.), APA handbook of research methods in psychology, Volume 2: Research designs: Quantitative, qualitative, neuropsychological, and biological (pp. 5-18). Washington, DC: American Psychological Association.

Porter, M. E., \& Kramer, M. R. (2011). The big idea: Creating shared value. Harvard Business Review, $89(1), 2-17$.

Prilleltensky, I. (2014). Justice and human development. International Journal of Educational Psychology, 3(3), 287-305.

Rauch, A., \& Frese, M. (2007). Let's put the person back into entrepreneurship research: A metaanalysis on the relationship between business owners' personality traits, business creation, and success. European Journal of Work and Organizational Psychology, 16(4), 353-385.

Rawls, J. (2001). Justice as fairness: A restatement. Cambridge, MA: Harvard University Press.

Reckase, M. (2009). Multidimensional item response theory. New York: Springer.

Reichman, W. (Ed). (2014). Industrial and organizational psychology help the vulnerable: Serving the underserved. New York: Springer.

Renouard, C. (2011). Corporate social responsibility, utilitarianism, and the capability approach. Journal of Business Ethics, 98(1), 85-97.

Ruggs, E. N., Hebl, M. R., Rabelo, V. C., Weaver, K. B., Kovacs, J., \& Kemp, A. S. (2016). Baltimore is burning: Can IO psychologists help extinguish the flames? Industrial and Organizational Psychology, 9(3), 1-23.

Ruggs, E. N., Law, C., Cox, C. B., Roehling, M. V., Wiener, R. L., Hebl, M. R., \& Barron, L. (2013). Gone fishing: I-O psychologists' missed opportunities to understand marginalized employees' experiences with discrimination. Industrial and Organizational Psychology, 6(1), $39-60$.

Rupp, D. E., \& Mallory, D. B. (2015). Corporate social responsibility: Psychological, person-centric, and progressing. Annual Review of Organizational Psychology and Organizational Behavior, 2(1), 211-236.

Rupp, D. E., Skarlicki, D., \& Shao, R. (2013). The psychology of corporate social responsibility and humanitarian work: A person-centric perspective. Industrial and Organizational Psychology, 6(4), 361-368.

Ryan, A. M., \& Gelfand, M. (2012). Going global: Internationalizing the organizational psychology curriculum. In F. T. L. Leong, W. E. Pickren, M. M. Leach, \& A. J. Marsella (Eds.), Internationalizing the psychology curriculum in the United States (pp. 245-261). New York: Springer.

Ryan, R. M., \& Deci, E. L. (2000). Self-determination theory and the facilitation of intrinsic motivation, social development, and well-being. American Psychologist, 55(1), 68-78. 
Saxena, M., Sall, E., Scott, J. C., Rupp, D. E., Saari, L., Foster, L., ... Mallory, D. (2015). News from the SIOP-United Nations team: Exploring work experiences of informal workers and promoting decent work for all. The Industrial-Organizational Psychologist, 53(1), 172-175.

Schein, V. E. (2012). Women, work, and poverty: Reflections on research for social change. In S. C. Carr, M. MacLachlan, \& A. Furnham (Eds.), Humanitarian work psychology (pp. 249-265). London: Palgrave Macmillan.

Schwartz, B. (2000). Self-determination: The tyranny of freedom. American Psychologist, 55(1), 79-88.

Schwartz, S. H. (1992). Universals in the content and structure of values: Theoretical advances and empirical tests in 20 countries. Advances in Experimental Social Psychology, 25, 1-65.

Scott, J. C. (2011). SIOP granted NGO consultative status with the United Nations. The IndustrialOrganizational Psychologist, 49(2), 111-113.

Sen, A. (1992). Inequality reexamined. Oxford, UK: Clarendon Press.

Sen, A. (1999). Development as freedom. New York: Oxford University Press.

Sen, A. (2009). The idea of justice. Cambridge, MA: Harvard University Press.

Shouksmith, G. (1996). History of psychology in developing countries. In S. C. Carr \& J. F. Schumaker (Eds.), Psychology and the developing world (pp. 15-25). London: Praeger.

Shrivastava, S., Jones, R., Selvarajah, C., \& Van Gramberg, B. (2016). Organisational justice: A Senian perspective. Journal of Business Ethics, 135(1), 99-116.

Singh, G. K., \& Siahpush, M. (2006). Widening socioeconomic inequalities in US life expectancy, 1980-2000. International Journal of Epidemiology, 35(4), 969-979.

Spreitzer, G. M. (2008). Taking stock: A review of more than twenty years of research on empowerment at work. In C. Cooper \& J. Barling (Eds.), Handbook of organizational behavior (pp. 54-73). Thousand Oaks, CA: Sage.

Stainback, K., Tomaskovic-Devey, D., \& Skaggs, S. (2010). Organizational approaches to inequality: Inertia, relative power, and environments. Annual Review of Sociology, 36, 225-247.

Tay, L., Meade, A. W., \& Cao, M. (2015). An overview and practical guide to IRT measurement equivalence analysis. Organizational Research Methods, 18(1), 3-46.

Tickameyer, A. R., \& Duncan, C. M. (1990). Poverty and opportunity structure in rural America. Annual Review of Sociology, 16, 67-86.

Trimble, J. E., Scharrón-del Río, M., \& Casillas, D. (2014). Ethical matters and contentions in the principled conduct of research with ethnocultural communities. In F. T. L. Leong, L. Comas-Dias, G. N. Hall, V. McLloyd, \& J. E. Trimble (Eds.), APA handbook of multicultural psychology (pp. 59-82). Washington, DC: American Psychological Association.

Umberson, D., Olson, J. S., Crosnoe, R., Liu, H., Pudrovska, T., \& Donnelly, R. (2017). Death of family members as an overlooked source of racial disadvantage in the United States. Proceedings of the National Academy of Sciences of the United States of America, 114(5), 915-920.

UN (United Nations). (2016). Behavioural insights at the United Nations: Achieving agenda 2030. United Nations.

UNDP (United Nations Development Programme). (1990). Human development report. Retrieved from www.undp.org.

UNDP (United Nations Development Programme). (2014). Barriers and opportunities at the base of the pyramid: The role of the private sector in inclusive development. Retrieved from www.undp.org.

UNDP (United Nations Development Programme). (2015a). Human development report: Work for human development. Retrieved from www.undp.org.

UNDP (United Nations Development Programme). (2015b). Human development reports: Public data explorer. Retrieved from www.undp.org.

UNICEF (United Nations Children's Fund). (2016). Child labour: Current status + progress. Retrieved from www.unicef.org.

Van de Vliert, E. (2013). Climato-economic habitats support patterns of human needs, stresses, and freedoms. Behavioral and Brain Sciences, 36(5), 465-480.

Weiss, H. M., \& Rupp, D. E. (2011). Experiencing work: An essay on a personcentric work psychology. Industrial and Organizational Psychology, 4(1), 83-97. 
Wilkinson, R. G., \& Pickett, K. E. (2006). Income inequality and population health: A review and explanation of the evidence. Social Science and Medicine, 62, 1768-1784.

World Bank. (2012). World Development Report 2013: Jobs. Washington, DC: Author. doi: 10.1596/978-0-8213-9575-2

Zickar, M. J., \& Highhouse, S. (2001). Measuring prestige of journals in industrial-organizational psychology. The Industrial-Organizational Psychologist, 38(4), 29-36.

\section{Appendix}

To estimate the incidence of populations and contexts affected by poverty, we attempted to identify the role of country contexts in the dominant narrative of I-O psychology and then characterize those country contexts in terms of multidimensional poverty. To estimate the incidence of country contexts in the I-O psychology dominant narrative, we conducted three different searches of the PsycINFO database for articles in I-O psychology journals. We analyzed the content of peer-reviewed journals because of their importance in shaping the dominant narrative within the field of I-O psychology. For all three searches, we limited results to the 23 journals that Zickar and Highouse (2001) classified as common outlets for I-O psychology research. A total of 57,516 journal articles published from 1917 to 2016 was gathered in a search for all available articles from the target journals.

The first search was based on country names and utilized PsycINFO's location-specific search field as a way to identify studies that considered each of 188 country contexts from UNDP (2015a). This field is "a standardized description of continents, regions, and country names related to the content of the document" (American Psychological Association, 2017). The second search was based on country names and utilized PsycINFO's all-text search field. The third search was based on nationalities and also utilized the all-text search field. For the second search, we used multiple alternative names in addition to the official United Nations name (UNDP, 2015b) whenever alternatives were listed in the United States Central Intelligence Agency's (CIA's) World Factbook (www.cia.gov). Alternative names included official long-form names, official short-form names, unofficial names, outdated names, and names of countries in the dominant local language in English characters. For the third search, we searched for both nouns and adjectives associated with the nationalities of each country, again using terms from the CIA's World Factbook.

Each search yielded a count of articles. For each search, we calculated each country's percentage representation among all articles retrieved. For the purposes of enhanced reliability, we then averaged country article representation from the three searches. Aggregation appeared justified in light of a high Cronbach alpha value of 0.91 . If a country's average article representation was larger than its share of the total population of the 188 countries for which we had population data from UNDP (2015a), then it was classified as "well-represented." If a country's average article representation was smaller than its population share, it was classified as "underrepresented." If a country was not identified in the three searches, then it was classified as "unrepresented." Country categorizations are listed in Table A1. To reduce the degree to which categorization could be misleading due to small country populations, we excluded the 44 countries with populations less than 2 million people. 
Table A1. Representation Levels of Countries

\begin{tabular}{|c|c|c|c|}
\hline \multirow{2}{*}{$\begin{array}{l}\text { Well-represented } \\
\text { countries } \\
\text { Country name }\end{array}$} & \multicolumn{2}{|c|}{ Underrepresented countries } & \multirow{2}{*}{$\begin{array}{l}\text { Unrepresented } \\
\text { countries } \\
\text { Country name }\end{array}$} \\
\hline & Country name & Country name & \\
\hline Australia & Afghanistan & Mali & Benin \\
\hline Austria & Albania & Mexico & Burkina Faso \\
\hline Belgium & Algeria & $\begin{array}{l}\text { Moldova (Republic } \\
\text { of) }\end{array}$ & Burundi \\
\hline Canada & Angola & Mongolia & $\begin{array}{l}\text { Central African } \\
\text { Republic }\end{array}$ \\
\hline Croatia & Argentina & Morocco & Eritrea \\
\hline Czech Republic & Azerbaijan & Mozambique & Kyrgyzstan \\
\hline Denmark & Bangladesh & Myanmar & Libya \\
\hline Finland & Belarus & Namibia & Mauritania \\
\hline France & $\begin{array}{l}\text { Bolivia } \\
\quad \text { (Plurinational } \\
\text { State of) }\end{array}$ & Nepal & Rwanda \\
\hline Germany & $\begin{array}{l}\text { Bosnia and } \\
\text { Herzegovina }\end{array}$ & Nicaragua & Senegal \\
\hline Greece & Botswana & Niger & South Sudan \\
\hline $\begin{array}{l}\text { Hong Kong, China } \\
\text { (SAR) }\end{array}$ & Brazil & Nigeria & \\
\hline Hungary & Bulgaria & Oman & \\
\hline Ireland & Cambodia & Pakistan & \\
\hline Israel & Cameroon & Panama & \\
\hline Italy & Chad & Papua New Guinea & \\
\hline Japan & Chile & Paraguay & \\
\hline Korea (Republic of) & China & Peru & \\
\hline Kuwait & Colombia & Philippines & \\
\hline Lebanon & Congo & Poland & \\
\hline Netherlands & $\begin{array}{l}\text { Congo (Democratic } \\
\text { Republic of the) }\end{array}$ & Qatar & \\
\hline New Zealand & Côte d'Ivoire & Romania & \\
\hline Norway & Cuba & Russian Federation & \\
\hline Palestine, State of & Dominican Republic & Saudi Arabia & \\
\hline Portugal & Ecuador & Serbia & \\
\hline Singapore & Egypt & Sierra Leone & \\
\hline Slovenia & El Salvador & Slovakia & \\
\hline Spain & Ethiopia & South Africa & \\
\hline Sweden & Georgia & Sri Lanka & \\
\hline
\end{tabular}


Table A1. Continued

\begin{tabular}{|c|c|c|c|}
\hline \multirow{2}{*}{$\begin{array}{l}\text { Well-represented } \\
\text { countries } \\
\text { Country name }\end{array}$} & \multicolumn{2}{|c|}{ Underrepresented countries } & \multirow{2}{*}{$\begin{array}{l}\text { Unrepresented } \\
\text { countries } \\
\text { Country name }\end{array}$} \\
\hline & Country name & Country name & \\
\hline Switzerland & Ghana & Sudan & \\
\hline United Kingdom & Guatemala & Syrian Arab Republic & \\
\hline \multirow{19}{*}{ United States } & Guinea & Tajikistan & \\
\hline & Haiti & $\begin{array}{l}\text { Tanzania (United } \\
\text { Republic of) }\end{array}$ & \\
\hline & Honduras & Thailand & \\
\hline & India & $\begin{array}{l}\text { The former Yugoslav } \\
\text { Republic of } \\
\text { Macedonia }\end{array}$ & \\
\hline & Indonesia & Togo & \\
\hline & $\begin{array}{l}\text { Iran (Islamic } \\
\text { Republic of) }\end{array}$ & Tunisia & \\
\hline & Iraq & Turkey & \\
\hline & Jamaica & Turkmenistan & \\
\hline & Jordan & Uganda & \\
\hline & Kazakhstan & Ukraine & \\
\hline & Kenya & $\begin{array}{l}\text { United Arab } \\
\text { Emirates }\end{array}$ & \\
\hline & $\begin{array}{l}\text { Lao People's } \\
\text { Democratic } \\
\text { Republic }\end{array}$ & Uruguay & \\
\hline & Latvia & Uzbekistan & \\
\hline & Lesotho & $\begin{array}{l}\text { Venezuela } \\
\quad \text { (Bolivarian } \\
\text { Republic of) }\end{array}$ & \\
\hline & Liberia & Viet Nam & \\
\hline & Lithuania & Yemen & \\
\hline & Madagascar & Zambia & \\
\hline & Malawi & Zimbabwe & \\
\hline & Malaysia & & \\
\hline
\end{tabular}

